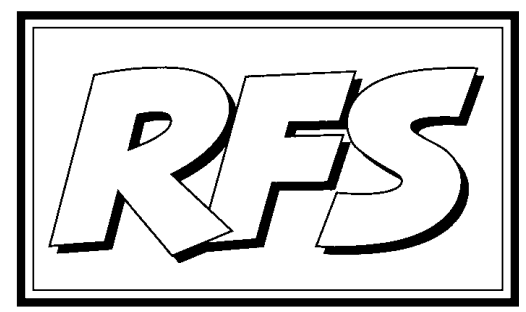

Revista de Fomento Social, 58 (2003), 681-728

\title{
El planeta agua
}

Gaspar RUL-LÁN BUADES ${ }^{1}$

(Palabras clave: Agua, conflictos sobre el agua, derechos fundamentales

Key Words: Water, CONFLICTS ABOUT WATER, FUNDAMENTAL RIGHTS)

\section{Introducción}

Este planeta se debería llamar agua... y no tierra. Más de tres cuartas partes de este pequeño planeta están cubiertas por agua y, gracias a la presencia de este elemento líquido, han podido surgir en él, a través de millones de años, innumerables formas de vida vegetal y animal. $Y$, sin embargo, a pesar de esta abundancia de agua en la tierra, la disponibilidad de agua apta para el consumo humano y para los regadíos es uno de los retos más graves con que se enfrenta la humanidad a principios de este siglo XXI. «La falta de acceso al agua para beber, para higiene y para la seguridad alimentaria -decía el Secretario de las Naciones Unidas, Kofi Annan al declarar el año de 2003 Año Internacional del Agua Dulce- inflige miseria en más de mil millones de miembros de la familia humana. Es probable que el agua se convierta en una creciente fuente de tensión y la causa de una

1 Profesor de la Facultad de Ciencias Económicas y Empresariales-ETEA. 
competencia violenta entre naciones, si las tendencias actuales continúan, pero también puede ser, si queremos, un catalizador para la cooperación». La humanidad va tomando conciencia del problema del hambre, pero quizás todavía no ha tomado conciencia del problema de la sed y, sin embargo, más gente muere por falta de agua que por falta de alimentos. El agua escasa se ha convertido en un bien estratégico. Quien en el futuro disponga de agua suficiente y de buena calidad, gozará de una ventaja política, económica y social sobre los que están privados de este precioso elemento.

El presente ensayo es un intento de ver la importancia del agua en la vida y los problemas a los que nos podemos enfrentar en el futuro no lejano si no tomamos conciencia de que el agua es, a pesar de su abundancia global, un bien que hay que gestionar racionalmente y distribuir equitativamente. El ensayo analizará el agua primero en las primitivas cosmogonías como fuente de vida, luego el agua como fuente de las civilizaciones, pero también como fuente de conflictos, para finalmente, analizar la situación actual de tan preciado bien en el mundo y sugerir las posibles líneas de actuación, una vez se ha reconocido el agua como derecho fundamental esencial para asegurar un nivel de vida adecuado para cada individuo y para el desarrollo sostenido de la humanidad.

\section{El agua fuente de vida}

\subsection{La relación del hombre con el agua}

Cuando el hombre dejó de ser un mero recolector-cazador y decidió «dominar la tierra» arándola y plantando semillas en su seno, se vio forzado a establecer una íntima y vital relación con el agua. Como cazador-recolector tenía una actitud pasiva frente a la tierra en la que, en cada momento, vivía: recogía los frutos, vegetales y animales que la tierra le ofrecía, y cuando ésta estaba exhausta y ya no podía dar más, el recolector-cazador emigraba a otras tierras en busca de su alimento. Pero la primera vez que el hombre removió la tierra con su (rústico) bastón arado y sembró una semilla, se vio forzado a establecer un diálogo permanente con el otro elemento, el agua, pues sin ella todos sus esfuerzos para hacer la tierra fértil eran inútiles. El hombre agricultor sometió la tierra a su dominio, pero no pudo someter el agua; él preparaba la tierra y las simientes, pero los dioses, a veces de forma caprichosa, daban el agua. Eran fuerzas extrañas y superiores, que se 
escapaban a la comprensión del hombre primitivo, las que mandaban las Iluvias que la tierra sembrada necesitaba o hacían correr los arroyos y los ríos.

Así pues, es natural que estos primeros pueblos agrícolas viesen el agua como fuente de vida. Pero estos dioses que controlaban el agua, y por tanto también la vida, a veces se enfadaban por el mal comportamiento de los hombres, y los castigaban, bien dejando de mandar el agua que los campos necesitaban o, lo que era casi peor, mandando un diluvio que lo arrasase todo. Pero los dioses, dueños de las aguas, estaban dispuestos a escuchar las súplicas de los hombres, y apiadándose de ellos hacían retroceder las aguas, y las tierras abonadas por el humus volvían a florecer llenas de vida, realizándose así una vez más, el ciclo perenne de vida, muerte y resurrección.

\subsection{El agua fuente de vida en las primeras cosmogonías}

Son innumerables los relatos de un océa no cósmico que cubre todo el universo y que Dios llega a controlar, separándolo de la tierra para que pueda vivir en ella el hombre. Probablemente una de las primeras cosmogonías que tienen el agua como elemento primigenio es la narración babilónica de Enema Elisa ( «Cuando allá arriba») según la cual los dioses más antiguos son dioses de las aguas: Aspa, el dios masculino de las aguas dulces, los ríos, las fuentes y la laguna que se encuentra en la desembocadura de los dos ríos y Taima, la diosa de las aguas saladas y del mar. De la unión de estos dos nació primero Marduk, el salvador y redentor y luego los dioses menores. A este primer acto de la creación siguió la lucha entre el caos y el orden, que terminó con la victoria de éste, lo que supuso la separación de las aguas de la tierra firme, el día de la noche, y la creación del hombre como responsable del mantenimiento de este orden.

Parece muy probable que la narración bíblica de la creación, tal como aparece en el Génesis, aparte de su significado religioso, estuviese influenciada por esta narración babilónica. En la Biblia leemos que «en un principio... el espíritu de Dios revoloteaba sobre las aguas», luego viene la separación de la luz de las tinieblas, después Dios crea un firmamento que separe las aguas que hay debajo de las que hay sobre él, luego Dios reúne en un solo lugar las aguas inferiores y las separa de la tierra y así sucesivamente hasta el último día en que Dios crea al hombre a su imagen y semejanza.

Prácticamente en todas partes del mundo: entre los kogis de Colombia, los 
yojutos yauelmanis de Norte América, los maoríes de Nueva Zelanda o los bantúes y dogó de África, se han conservado similares relatos que describen una época cósmica en la que en un principio el universo yacía en tinieblas anegado por las aguas que lo cubrían todo, pero el Ser Supremo, de alguna manera, las llegó a controlar para sacar de ellas la vida. Según una cosmogonía y teogonía del antiguo Egipto, «en un principio existía el océano primordial, Nun y su esposa Naunet, el doble cielo bajo la superficie de la tierra y de esta agua cósmica salió el gran dios Atum y creó un lugar seco donde poner sus pies». En la China, una tradición que data del tercer milenio a.C. describe también una lucha cósmica entre los cielos y el agua en la que el Gran Yu trabaja durante nueve años cavando canales por donde pueda discurrir el agua, para que la tierra se seque y pueda crear al hombre. Y unos escritos en bambú, del siglo IV a.C., descubiertos recientemente hablan también del «Tayi sheng shui»(El Gran Ser Creador del Agua) del que surgen los cielos y la tierra.

Otra variante de estos relatos cosmogónicos es la historia de la inmersión en el agua de la que saldrá el mundo, que se encuentra en la mayoría de los pueblos de Asia central así como en la India y en algunos pueblos de Norteamérica, como los maidus de California. Según este mito, en un principio es todo agua y, o bien el mismo Dios se sumerge en el agua y saca un poco de limo, o bien manda un animal que se sumerja y traiga el barro que hay en el fondo, para con él crear el mundo.

La idea de identificar los mares primigenios con una serpiente se encuentra en tradiciones tan dispares y distantes en tiempo y lugar como los mayas y los hindúes y algunos pueblos de Indonesia. Una narración del pueblo maya nos dice que «en un principio no había más que inmovilidad y silencio en las tinieblas y en la noche. Estaba sólo el Creador y Gugumatz, la Serpiente emplumada, los que engendran, los que dan vida, solos sobre las aguas como una luz encendida».

La idea de un diluvio universal no es patrimonio exclusivo del pueblo de Israel. En la Biblia leemos que, viendo Dios la maldad de los hombres, decide exterminarlos, excepto a su elegido, Noé y, para ello, hace llover sobre la tierra durante cuarenta días y cuarenta noches, hasta que las aguas lo cubren todo y hacen subir la barca de Noé hasta la cima de una montaña, salvándose así y convirtiéndose en el padre de todas las futuras generaciones. Pero ya anterior al relato bíblico, en la «Épica de Guilgamesh», un poema sumerio del siglo VII a.C., se cuenta que los dioses destruyeron la antigua ciudad de 
Shuruppak mediante una gran inundación, pero Utnapishtim, advertido por Ea, logró so brevivir construyendo una gran nave. Y relatos muy similares, de unas grandes inundaciones de las que se salva sólo una pareja, hombre y mujer, que son los progenitores de la raza humana, se han conservado en la memoria de muchos otros pueblos tan dispares como los de Indonesia o algunas islas del Pacífico, así como entre los secoyas de Ecuador y los tacanas de Bolivia.

Pero, sin duda, es en la India donde se encuentran más desarrolladas estas cosmogonías que, en las diversas formas mencionadas, dan al agua el papel principal en la creación de la tierra y del hombre. Ya en el Rigveda, uno de los textos más antiguos de los invasores arios de la India, leemos: «Entonces... el Uno existía entonces y ningún otro. Al principio sólo había tinieblas envueltas en tinieblas. Todo era tan sólo agua no iluminada» (Rigveda X.129). En las Ilamadas Leyes de Manu, que datan del siglo II a.C., se dice: «El Auto-existente, deseando producir de su propio cuerpo seres de muchas clases, con un pensamiento creó primero las aguas y puso en ellas su semilla. Esta semilla se convirtió en un huevo de oro, en este mismo huevo nació él como Brahma, progenitor de todo el mundo» (Leyes de Manu I 5-16). En los textos más filosóficos de los Upanishads,en los que se reúne la esencia del monismo hindú, se encuentran expresiones como esta: «en un principio no había absolutamente nada, entonces Él pensó, 'ojalá tuviese un yo' y se puso a orar y, mientras oraba, de Él surgió el agua, y la espuma del agua se solidificó y así se formó la tierra» (Brihadaranyaka Upànishad.I-2, 1-3) .

Es, sin embargo, en los populares Puranas, redactados en fechas muy posteriores, donde se encuentran las más detalladas narraciones de la creación del mundo por el agua. La historia más conocida es la de Vishnu. El Absoluto se manifiesta de tres formas distintas como Trimurty: Brahma el creador, Vishnu el protector y Shiva el destructor, tres manifestaciones de la Única realidad existente. Vishnu, probablemente en sus orígenes una divinización del sol, surge del mar, es decir de la nada cósmica antes de la creación. La imagen más popular de Vishnu es la de esta manifestación de dios recostado en la gran serpiente Shesha, de mil cabezas de cobra, que flota en el océano cósmico, mientras que de sus entrañas surge una flor de loto en la que está sentado Brahma el creador. 


\subsection{El agua fuente de vida espiritual}

No se puede ignorar, tampoco, el significado espiritual que tiene el agua como elemento capaz de traer vida al alma, muerta por el pecado. El agua como elemento de purificación antes de acercarse a hacer los sacrificios; el agua necesaria para renacer a la vida de la gracia por el bautismo; Jesús ofrece a la Samaritana el agua de la vida; Dios mismo en el Viejo Testamento se proclama «fuente de agua viva» (J er. 2,13$)$, y el agua aparece como fuente de gracia del nuevo templo (Ez. 47, 1 y seg.).

En la India las aguas del río Ganges sirven para limpiar al hombre de todos sus pecad os y darleuna nueva vida. En la mitología hindú es tanta la perfección de la diosa Ganga (el río Ganges) que es considerada hija de Brahma, la esposa de Shiva y la melodía de Vishnu. Millones de indios sueñan con un día poder ir a bañarse en las aguas del sagrado río para volver a nacer, no sólo limpios de todos sus pecados pasados, sino fortalecidos para no pecar más.

En muchos pueblos los ríos y los mares o eran divinizados o estaban poblados por dioses y otros seres celestiales. En Egipto divinizaron al Nilo, los etolios al Aqueolo, los frigios al Escamandro, los lacedemonios al Eurotas, los atenienses al Iliso y los romanos al Tiber. En Grecia los «daimones»eran las fuerzas de la naturaleza personalizadas y divinizadas, y así se habla de un polidaimonismo griego. La historia del arte nos muestra que los griegos tenían una gran abundancia de espíritus de las aguas, no todos los cuales pertenecían al séquito de Poseidon, dios de los mares. Los dioses del mar, «Theoi Einalioi», y los espíritus de los mares, «Daimones Einalioi», eran no menos de veinticinco, y Zeus, la divinidad suprema del panteón griego era originalmente el dios de las tormentas, identificado con Wodan y con el Thor germánico, aunque luego se convirtió en el vencedor del mal, que hace reinar el orden, la sabiduría y la justicia. En Roma tenemos a Neptuno, dios del mar rodeado de sus Tritones y enamorado de Anfitrite, hija de Océano y Tetis, de cuya unión nacieron los Ríos y los Oceánides, a los que deberían unirse en este panteón los otros dioses menores del mar como Nereo, Aretusa, Proteo, Orco y el pescador Glauco, sin olvidar las Náyades o ninfas que imperaban sobre los ríos, los torrentes y las fuentes.

\subsection{El agua como fuente de vida biológica}

Pero no sólo en las antiguas cosmogonías aparece el agua como fuente de vida mitológica y espiritual sino que la ciencia nos ha mostrado más allá de 
cualquier duda que el agua es también, en efecto, la fuente de toda vida biológica. Sin el simplecompuesto químico de dos átomos de hidrógeno y uno de oxígeno, lo que llamamos agua, la vida no sería posible. El agua participa prácticamente en to dos los procesos de las plantas y de los animales. El agua está encima denosotros, debajo de nosotros y dentro de nosotros. Casi el $80 \%$ del peso de la persona humana es agua. Nuestro mismo cerebro es en un $80 \%$ agua. El cuerpo humano contiene alrededor de 38 litros de agua y necesita reponer unos dos litros al día. Todos los ciclos de la vida dependen del agua. La vida en nuestro planeta, cubierto en tres cuartas partes por agua, sería imposible sin la capacidad del agua de fluir y cambiar de estado, de líquido a vapor con el calor, evaporándose paulatinamente, lo que acarrea los fenómenos atmosféricos que originan la posterior precipitación de esevapor de agua de distintas maneras; precipitaciones que nutren los ríos, y surten los acuíferos subterráneos, por medio de las filtraciones, constituyendo así depósitos naturales de aguas subterráneas. Por el contrario, pasando de liquido a sólido a 0 , aumentando su volumen un $10 \%$, le permite flotar hacia el sur en los océanos y derretirse al llegar a aguas más cálidas, enfriando las aguas, mientras los vientos y las mareas llevan el calor de los océanos hacia los polos, creándose así un ciclo vital para la vida en nuestro planeta.

El océano es el lugar del que surgió la vida. Hace más de 3.500 millones de años, evolucionaron algas y bacterias unicelulares muy similares a las que constituyen hoy la base de la vida en los océanos. Conocida con el nombre de fitoplacton esta microflora explota la energía del sol y los nutrientes disueltos en el agua, para fabricar moléculas de tejido vivo. Al ser dependiente de la luz solar, el fitoplacton florece en una delgada capa en la superficie del océano, formando una biosfera que no pasa de los cien metros de profundidad que genera 16.000 millones de toneladas de carbono al año, la materia básica del tejido viviente.

\section{El agua origen de las civilizaciones}

\subsection{La agricultura y las primeras ciudades}

La historia nos dice que hace unos 10.000 años que el hombre adoptó la agricultura cultivando plantas y criando animales. Con la agricultura, los grupos humanos pasaron, de un estado de continuos desplazamientos en busca de caza y frutos para recoger, a un estado sedentario en aldeas 
permanentes cercanas a fuentes de agua y rodeadas de las tierras de cultivo. Este nuevo modo de producción y estilo de vida fomentó el desarrollo de una arquitectura más estable y sofisticada que utilizaba nuevos materiales, no sólo para la vivienda sino también para almacenar las cosechas, y para actividades religiosas, y desarrolló nuevas técnicas en los aperos utilizados, como el arado de madera tirado por bueyes, en las variedades de semillas cultivadas y árboles plantados, y en la forma de cultivar: por regadío, en terrazas o por inundación, etc. Todo ello permitió la producción de un excedente dealimentos que propició la aparición del comercio, primero local y, más tarde, con la invención de la rueda y el carro y la mejora de los transportes fluviales, hasta regiones más lejanas, y permitió la creación de concentraciones de personas dedicadas a otros menesteres distintos de la agricultura y que formaron las primeras organizaciones urbanas o ciudades, dando origen a las civilizaciones. Todas estas ciudades se caracterizaban por una gran variedad de actividades que se desarrollaban en las mismas y la clara división del trabajo, lo que pronto daría lugar a la aparición de divisiones sociales más o menos rígidas: siervos, artesanos, administradores, sacerdotes, militares y, por debajo de todos ellos, los esclavos ganados en batallas o comprados en el mercado.

La ciudad se convertía en el núcleo central de toda una región rural, con grandes, sólidos y permanentes edificios, que sobresalían por encima de las viviendas y los talleres de artesanos, formándose así la típica concentración urbana de las primeras civilizaciones del pasado, todas ellas nacidas a orillas de unos grandes ríos para poder satisfacer las necesidades de agua y saneamiento de los habitantes de la ciudad, y de regadío para las tierras de cultivo circundantes: Mesopotamia, Egipto, Mohenjadaro y Harappa y Río Amarillo.

\subsection{Mesopotamia}

Mesopotamia, la tierra entre los dos ríos, Tigris y Eufrates, era una tierra pobre en materias primas, en minerales y en maderas; $y$, sin embargo, desde el cuarto milenio a.C. albergó una gran civilización con ciudades de decenas de miles de habitantes, una arquitectura monumental y un complejo sistema administrativo, y en la que se desarrollaron la literatura, las ciencias, un complejo sistema legal y, para llevar la contabilidad, una escritura cuneiforme que se utilizó durante 3.000 años y fue adoptada por muchos idiomas a lo largo y ancho de Asia occidental. Fue en Sumeria que se construyeron, con 
el adobe, hecho de arcilla, el único material disponible en la llanura fluvial, los que probablemente fueron los primeros núcleos urbanos importantes de la humanidad: Uruk, Eridu y Ur, núcleos que, en el tercer milenio a.C., seguirían desarrollando las civilizaciones mesopotámicas que sustituyeron a Sumeria, Babilonia en el sur y Asiria en el norte.

Sumeria era hija de los dos grandes ríos, y sin ellos no hubiese podido existir. El nacimiento de esta civilización fue posible gracias a la dominación de los dos ríos, con un sofisticado sistema de drenaje de las ciénagas, y el transporte de agua por canales de irrigación, lo que permitió el cultivo de cereales en las tierras fértiles. El Tigris y el Eufrates aumentaban su caudal al máximo en primavera y, por consiguiente, con frecuencia se desbordaban en esta época del año. Sin embargo, los agricultores necesitaban agua en sus campos no en primavera, sino a finales de verano y en otoño. Se enfrentaban, pues, al doble problema de retener el agua en primavera y liberarla en otoño. En Sumeria, a diferencia de lo que sucedía en las tierras cercanas al Nilo, como veremos más adelante, la mayor parte de la irrigación y el abono de las tierras no dependía de las inundaciones periódicas, sino del caudal constante de agua que fluye en los ríos durante todo el año y, para ello, se realizaron enormes obras de irrigación artificial que debían ser mantenidas constantemente.

\subsection{Egipto}

Durante casi 3.000 años, Egipto desarrolló una floreciente civilización gracias, como en el Medio Oriente, en la India y en la China, a las aguas de un gran río, que nace en las lejanas tierras de la región de los Grandes Lagos como Nilo Blanco, y en Etiopía como Nilo Azul, juntándose los dos en Sudan para entrar a regar y hacer fructificar una estrecha, pero fértil, franja de tierra de 1.200 kms. en el país de los faraones. Cada verano el Nilo se desbordaba en el momento apropiado del año, en agosto, arrastrando desde sus lejanas fuentes de las montañas etíopes y los lagos africanos, grandes cantidades de agua y ricos depósitos aluviales y sedimentos altamente fértiles que depositaba en los campos. El caudal del agua descendía convenientemente en otoño, permitiendo así la siembra de semillas y su germinación en los calurosos aunque templados meses de invierno y principios de la primavera. También se formaban extensos humedales que permitían la reproducción de aves y peces de agua dulce. Las áreas cenagosas en los márgenes y en el delta en la desembocadura del río en el Mediterráneo permitían el crecimiento de 
hierbas marginales y malezas. La economía, que debía su existencia al Nilo, comprendía una gran variedad de plantas, como el trigo, la cebada y el lino. Se criaban también animales con fines utilitarios y domésticos. El campesino egipcio estaba ocupado todo el año en sus tierras pues a cada inundación seguía una época de mucha actividad ya reestablecidos los límites del río una vez que las aguas habían bajado, para preparar las áreas aptas para el cultivo, sembrar, escardar y cosechar. Aunque en Egipto se hacía menor uso de los canales de irrigación que en Mesopotamia, era necesario también el limpiar y mantener en buen estado las acequias 0 , en las zonas más altas, reparar y mantener en buen estado el «shaduf»o especie de molino para elevar el agua.

En Egipto no se encontraban grandes núcleos urbanos, sino pequeños pueblos a lo largo del cauce del río Nilo, con unos pocos centros administrativos ubicados principalmente en el norte y en el sur, como los de Menfis y Tebas. El Nilo era prácticamente el único medio de comunicación y transporte de mercancías entre los pueblos asentados a lo largo del río; según un estudioso de esta civilización, quizás esta facilidad del transporte fluvial hizo que se descuidase el desarrollo de otras formas de transporte y comunicaciones como la rueda, el caballo o las carreteras.

\subsection{Civilizaciones del Indo}

También las primeras civilizaciones del subcontinente asiático florecieron alrededor de un sistema fluvial, el Indo y sus tributarios, en lo que hoy es Pakistán y el noroeste de la India. Durante la segunda mitad del tercer milenio a.C., floreció en esta parte del planeta una civilización de gran complejidad que ocupaba una vastazona de casi un millón dekms. cuadrados (mucho más grande que Mesopotamia y Egipto) y que tenía un largo acceso al mar de más de 1.200 kms., y cuya estructura descansaba sobreciudades, 250 delas cuales se han descubierto en el valle del Indo, siendo las más importantes las de Mohenja-Daro en el sur y la de Harappa en el norte, cuyas poblaciones pueden haber llegado a 40.000 habitantes. Una de las características más asombrosas de esta civilización del Indo son sus técnicas de planificación y edificación urbana. Las capitales fueron cuidadosamente planificadas. Con una ciudadela sobre un montículo y una segunda muralla defensiva alrededor del asentamiento. Las calles tenían forma de cuadrícula, en contraste con las caóticas y sinuosas calles de las ciudades de Mesopotamia. Es extraordinario también el cuidado que puso esta civilización en los sistemas de drenaje de los centros urbanos. Todas las calles tenían canales de desagüe 
de ladrillo con bocas de acceso a intervalos regulares. Casi todas las casas de Monjenja-Daro tenían un baño, y muchas un lavabo, conectados ambos a los canales de la calle mediante tuberías y sumideros de arcilla. Esta civilización desarrolló un floreciente comercio con otros países, por tierra y por mar con los países del centro de Asia y los del Golfo Pérsico, pero, finalmente, desapareció alrededor del año 2.000 a.C. con la llegada de las tribus arias de lengua indoeuropea, probablemente de la cercana Persia.

Es difícil saber si la población del valle del Indo practicó la irrigación a gran escala, pues los arqueólogos no han podido descubrir ninguna obra de irrigación antigua debido a que los depósitos aluviales han elevado la superficie del suelo unos diez metros desde el tercer milenio a.C. Con todo, los mismos estudiosos han señalado que probablemente la irrigación no era necesaria, pues los agricultores podrían haber utilizado, como los agricultores egipcios, las anuales crecidas del Indo que inundaban los campos, permitiendo que el trigo y la cebada se sembrasen cuando las aguas ya se retiraban, en otoño, y se recogiesen en primavera, sin casi necesidad de arar, abonar o regar las tierras.

\subsection{Civilización del río Amarillo}

En China, la civilización actual es la descendiente directa de la civilización Chang que surgió en el segundo milenio a.C., también como en Egipto, Mesopotamia y Mohenja-Daro, en la Ilanura aluvial de un gran río, el río Amarillo, en el norte de China. Sin embargo, el río Amarillo es un río salvaje mucho más difícil de controlar que el Nilo, el Tigris y Eufrates o el Indo, pues acarrea más lodo quecualquier otro gran río, y no posee un canal permanente de salida al mar, de modo que, salvo que se lo confine entre diques, puede cambiar su curso de forma impredecible. Más aún, a medida que se enfanga el río, los diques tienen que ser elevados, un proceso que continúa hasta que, en algunos lugares, el lecho del río queda más alto que la tierra circundante, naturalmente, si el río se desborda sobrevienen unas inundaciones catastróficas. No sabemos a ciencia cierta hasta qué punto la civilización Chang pudo controlar el río, ni siquiera conocemos a ciencia cierta el curso que tenía en aquella época. El río Amarillo acarrea agua y lodo fértil desde las tierras altas del oeste a la llanura seca del norte de China, y esto hace pensar que se debió practicar algún tipo de irrigación, que permitía la doble cosecha que no habría sido posible sin ella: mijo y arroz en la primera mitad del año y trigo y cebada en la segunda. 
Probablemente en la civilización Chang no había grandes núcleos urbanos como en Mesopotamia o en el valle del Indo. Tampoco se sabe con certeza qué territorio llegó a abarcar esa civilización Chang. Su centro era el valle bajo del río Amarillo, pero comerciaba con otras áreas hasta el río Yangtsé. En algún momento del siglo once a.C. los Chang fueron arrasados por un pueblo pastoril del oeste que fundó la dinastía Zhou bajo la cual la civilización china se extendió a lo largo del norte de China y empezó a abarcar el área de otro gran río, el Yangtsé, en el sur.

Esta misma agua, que todos los pueblos reconocieron como origen del univer so y fuente de vida y que dio a luz a las primeras grandes manifestaciones culturales del hombre, hoy poneen peligro a esta misma humanidad que ayudó a crear y a desarrollarse. Hoy el agua puede convertirse de fuente de vida en fuente de conflictos y de muerte, como veremos en el apartado siguiente.

\section{El agua fuente de conflictos y de muerte}

\subsection{El problema del agua en el mundo actual}

En 1992, con ocasión de la cumbre de la tierra celebrada en Río de Janeiro, Sandra Postel, Vicepresidenta para Investigación del prestigioso World Watch Institute, publicó un libro titulado «The Last Oasis: Facing Water Scarcity»que fue una de las primeras voces que se levantaron para que el mundo tomase conciencia de un problema gravísimo, que el agua que había sido el origen de la vida y de las más grandes civilizaciones, empezaba a escasear. Si no se tomaban medidas urgentes, en 30 años el hombre podría enfrentarse a un problema de dimensiones mundiales y de consecuencias desastrosas que influirían muy negativamente en el equilibrio ecológico de nuestro planeta, en la seguridad alimentaria del mundo, en las crecientes poblaciones urbanas, y en el desarrollo industrial y de nuevas tecnologías, llevando todo ello a una situación de inseguridad social y conflictos permanentes dentro de algunos estados y entre estados distintos. «os líderes políticos, infravaloran las consecuencias de la escasez de agua en la producción de alimentos, los ecosistemas naturales y la paz y estabilidad en distintas partes del mundo» decía la Profesora Postel. Millones de toneladas de grano se producen vaciando las capas freáticas, y en el próximo futuro el desvío del agua de la agricultura a las zonas urbanas y a la industria puede tener consecuencias desastrosas para la posible alimentación de las futuras generaciones. 
En nuestro planeta, el $97 \%$ del agua es salada y sólo el $3 \%$ es agua dulce. Pero aun este 3\% no es directamente utilizable por el hombre, pues el $79 \%$ está congelada en los casquetes polares y en los glaciares, el $20 \%$ está en acuíferos de difícil acceso, y sólo el $1 \%$ en aguas en la superficie de la tierra. $Y$ en este pequeño $1 \%$ hay que distinguir, todavía, entre el $38 \%$ que se encuentra en la humedad de la tierra, el $1 \%$ en los organismos vivos, el $8 \%$ en la atmósfera, el $52 \%$ en los lagos y el $1 \%$ en los ríos. A primera vista parecería que es muy poca el agua dulce disponible para la población mundial y, sin embargo, esta pequeña cantidad de agua dulce bastaría para abastecer a unos 13.000 millones de personas, más del doble de la población actual del mundo. Y, si pensamos en las posibilidades de desalinización de las aguas marinas, la disponibilidad de agua para el consumo humano es ilimitada. Sin embargo, hoy millones de seres humanos que carecen del mínimo esencial de agua para cubrir sus necesidades más elementales de beber, cocinar e higiene personal, y aun cuando tienen alguna agua a su disposición esta es de tan mala calidad que crea serios problemas de salud.

En la actualidad, 1.100 millones de personas, el 18\% de la población mundial, no tiene acceso al agua potable (en África esta cifra llega al 50\%) y 2.400 millones de personas, el $40 \%$ de la población mundial, carece de redes de saneamiento. Según la Organización Mundial de la Salud, cada año mueren 3,5 millones de personas por enfermedades derivadas de la mala calidad del agua que utilizan, como el paludismo, el cólera, la disentería, la esquistomatosis, la hepatitis infecciosa y la diarrea. Los más afectados por la falta de agua potable son los niños y niñas de corta edad, lo que causa unas 6.000 muertes diarias. La OMS ha calculado que el $70 \%$ de las muertes de niños y niñas pequeños del Tercer Mundo son debidas a deshidratación de sus débiles cuerpos a causa de las afecciones gastrointestinales debidas al agua contaminada que beben.

\subsection{Causas de la escasez del agua}

Muchas son las causas de este tremendo problema que debe que afrontar la humanidad hoy, y que deberá afrontar en los próximos años, y las podríamos clasificar de la siguiente manera:

-Crecimiento de la demanda

- Crecimiento de la población

- Crecimiento de la demanda de alimentos y de agua para la industria 
-Disminución de la oferta

- Mala distribución

- Mala gestión

- Contaminación

- Fugas

a) Crecimiento de la demanda

- Crecimiento de la población:

Con el ritmo actual de crecimiento de la población de unos 87 millones de personas al año, y un más rápido crecimiento de la demanda de agua, se calcula que dentro de sólo 30 años casi 3000 millones de personas sufrirán los problemas de escasez de agua. En los últimos 70 años el consumo del agua se ha multiplicado por 6 mientras que la población se ha multiplicado por 3 , o sea que el crecimiento del consumo de agua ha crecido a un ritmo que duplica el de la población. Sólo algunos ejemplos bastarán para darse cuenta del incremento enorme que va a sufrir la demanda de agua potable en unos pocos años: Ia India ya ha pasado los 1.000 millones de habitantes y la China superó hace tiempo los 1.200 millones, Pakistán en pocos años habrá pasado de 128 millones a 210 millones, Turquía se acerca a los 80 millones, Etiopía a los 85 y Egipto a los 82. El siguiente cuadro nos muestra el aumento de población y disponibilidad de agua en el Cercano Oriente con problemas de distribución de las aguas del Nilo y del Jordán.

CUADRO 1

\section{Crecimiento de población y de disponibilidad de agua}

\begin{tabular}{|l|c|c|c|c|}
\cline { 2 - 5 } \multicolumn{1}{c|}{} & \multicolumn{2}{c|}{ Población (millones) } & \multicolumn{2}{c|}{ Disponibilidad de agua } \\
\cline { 2 - 5 } \multicolumn{1}{c|}{} & Hoy & en $\mathbf{2 0 5 0}$ & $\mathbf{1 9 9 0}$ & en 2050 \\
\hline Egipto & 66 & 115 & 1.070 & 620 \\
\hline Etiopía & 62 & 212 & 2.360 & 980 \\
\hline Israel & 6 & 9 & 470 & 210 \\
\hline J ordania & 6 & 16 & 260 & 80 \\
\hline Líbano & 3 & 5 & 1.600 & 960 \\
\hline
\end{tabular}

Fuente: adaptado de Klare, M.T. (2003) pp. 187, 199 y 205. 
- Crecimiento de la demanda de alimentos y de agua para la industria

Actualmente el $70 \%$ del agua disponible para el hombre se utiliza en la agricultura. El área de riego del mundo, que supone el $16 \%$ del área cultivada y produce el $40 \%$ de los alimentos del mundo, va creciendo mucho más despacio queel crecimiento dela población: el total deárea regada en el mundo llegó a su máximo en 1979 y desde entonces ha disminuido un 7\%. Tres son los principales peligros que ha de superar el necesario aumento de la producción de alimentos si ha de poder hacer frente a la creciente demanda del aumento de la población humana. El primero es el desvío del agua de la producción de alimentos para los hombres a la producción de piensos para los animales para poder hacer frente a la creciente demanda del consumo de carne. Casi dos de cada cinco toneladas de grano se utilizan como alimentos para la producción de carne de reses y aves, y como dice Wouters, P. (2003) «quizás la humanidad tendrá que empezar a pensar en ciertos cambios dietéticos, consumiendo aquellos alimentos que menos agua necesiten para su producción».

El segundo peligro es la desviación del agua de las zonas rurales productoras de alimentos a las zonas urbanas consumidoras de alimentos. Con la perspectiva del crecimiento de la población urbana en 500 millones en el año 2050, la presión para dirigir a usos urbanos el agua que hoy se dedica a la agricultura será enorme. Entre 1950 y 1990 el número de ciudades con más de un millón de habitantes pasó de 78 a 290 y en el año 2025 se calcula que serán 650. La gran mayoría (alrededor de 250) están en los tres continentes más pobres, y diecisiete de ellas muy pronto tendrán más de 10 millones de habitantes. La ciudad de México tenía 1,5 millones de habitantes en 1940 y se acerca ya a los 20 millones. Shanghai de 5 millones en 1950 a 14 millones en 1990 y Yakarta de 1 millón en 1930 a 20 millones en la actualidad. Calcuta y Bombay ya pueden haber llegado a los 20 millones. Todos estos cientos de millones de habitantes de la ciudad no sólo necesitarán suficiente agua para sus necesidades personales y de ocio, sino enormes servicios de saneamiento y, lo que es más importante, más productos agrarios que sólo se podrán producir aumentando las zonas de regadío.

El tercer peligro será el desvío del agua de la agricultura a la industria, donde es mucho más rentable. Se necesitan 1.000 toneladas de agua para producir una tonelada de grano, con un valor de $25 \$$, mientras que si se usa esta misma cantidad de agua para la industria se puede aumentar el valor de la producción hasta 14.000 \$. Se calcula que en los próximos 50 años el consumo industrial del agua se doblará, y en la China se multiplicará por cinco. 


\section{b) Disminución de la oferta de agua}

Pero mientras la demanda de agua dulce irá en aumento, la tendencia actual es de una clara disminución de la oferta de tan preciado líquido. El agua disponible en nuestro planeta es un bien finito, escaso y frágil y, mientras la demanda de agua va en aumento, la oferta no sólo no sigue estable sino que va disminuyendo progresivamente por varias causas. La primera es la sobreexplotación de las fuentes superficiales y subterráneas de agua. En extensas áreas de cultivo del norte de la China el nivel de agua de las capas freáticas está bajando un metro cada año, y en el Punjab indio, el granero del país, el nivel freático baja unos $20 \mathrm{cms}$ al año. En los últimos 10 años la parte baja del río Amarillo en China se ha secado anualmente por unos 70 días, y en 1995 estuvo seco por 122 días. El mar de Aral ha perdido la mitad de su área y tres cuartas partes de su volumen, debido a las múltiples desviaciones que han sufrido los ríos que lo alimentaban, para poder aumentar el área de regadío de los campos de algodón. En este mismo mar de Aral, 20 de las 24 especies de peces que existían en estas aguas han desaparecido, y lo mismo el volumen de pesca, que llegó a ser de 44.000 toneladas al año, dando trabajo a más de 60.000 personas. California ha perdido el $95 \%$ de sus zonas húmedas disminuyendo su población de aves migratorias y autóctonas y bajando su población de unos 6 millones de aves a menos de 3 millones en el día de hoy, y el río Colorado ya, con frecuencia, se seca en su desembocadura sin que lleguen sus aguas al Golfo de California. Esa disminución de estos ríos y otros muchos ha hecho que sus estuarios se hayan convertido en no aptos para la fauna marina debido al poco caudal de agua que llega al mar. La construcción de grandes presas (en 1950 había en el mundo 5.000 grandes presas mientras que hoy son más de 40.000) junto con las numerosas desviaciones de cauces fluviales, han destruido el equilibrio ecológico de grandes zonas del planeta. $Y$ a todo ello hay que añadir, como veremos inmediatamente, el aumento de zonas conflictivas del planeta por el control de los cauces de ríos transfronterizos.

El fenómeno del calentamiento del planeta también ha influido en el pasado, y puede influir más en el futuro, en la disminución del agua dulcepara consumo humano. En el océano Ártico la capa de hielo ha disminuido un $40 \%$ en los últimos 35 años, y expertos noruegos han vaticinado que, si este proceso no se revierte, en 50 años puede que en los meses de verano el océano Ártico esté sin hielo, lo que afectará seriamente a las corrientes oceánicas. Pero no sólo el hielo se está fundiendo en las zonas árticas, también está disminuyendo peligrosamente en muchos sistemas montañosos, afectando seriamente el caudal de los ríos. Este mismo calentamiento 
puede producir una elevación del nivel del mar, lo que supondrá que las aguas saladas entrarán en los cauces de los ríos, destruyendo los cultivos de sus desembocaduras. Finalmente, la continua deforestación que sufre la masa verde del planeta afecta seriamente tanto a la cantidad de agua de lluvia que llega a la tierra, como a la capacidad de retenerla para usos humanos

- Mala distribución

Aunque en los años ochenta la demanda de agua anual fue del orden de $2.800 \mathrm{~km}$. cúbicos, y la oferta fue de $42.000 \mathrm{~km}$. cúbicos, podríamos pensar que no tendría que haber problemas de abastecimiento para todo el mundo, pero sin embargo, la mala distribución de esta agua hace que este líquido vital sea un gravísimo problema tanto a nivel personal como a nivel de comunidades enteras y hasta de países y continentes. No es que no haya suficiente agua para satisfacer las necesidades de todo el mundo, es que el agua disponible para usos domésticos está muy mal distribuida. Mientras que África, con el $13 \%$ de la población mundial, sólo tiene el $11 \%$ del agua disponible, Estados Unidos de América, que sólo tiene el $8 \%$ de la población mundial, dispone del $15 \%$ del agua dulce del planeta. América del Sur tiene el $5 \%$ de la población mundial y el $26 \%$ del agua disponible, y Australia el $1 \%$ de la población y el $5 \%$ del agua. Finalmente, Europa tiene el 13\% de la población mundial y el $8 \%$ del agua del mundo y Asia, con más de la mitad de la población mundial (60\%), sólo dispone del $35 \%$ del agua dulce del planeta.

CUADRO 2

Recursos hídricos y población mundial

\begin{tabular}{|l|c|c|c|c|c|c|}
\cline { 2 - 7 } \multicolumn{1}{c|}{} & Europa & Asia & África & $\begin{array}{c}\text { América } \\
\text { del Norte }\end{array}$ & $\begin{array}{c}\text { América } \\
\text { del Sur }\end{array}$ & Oceanía \\
\hline \% población & 13 & 60 & 13 & 8 & 5 & 1 \\
\hline$\%$ agua & 8 & 36 & 11 & 15 & 26 & 5 \\
\hline
\end{tabular}

Fuente: Fernández-Jáuregui (2003).

Pero no sólo el agua está mal distribuida entre continentes: dentro de los mismos continentes la distribución del agua entre los distintos sectores de 
producción es también muy desigual. Mientras en Asia y África más del $80 \%$ del agua ( $85 \%$ y $88 \%$ respectivamente) se utiliza para la agricultura, en Europa y en Estad os Unidos de América menos del 40\% (31\% y 39\% respectivamente) se dedica al campo. Por el contrario, mientras en los dos continentes de Asia y África el agua utilizada para fines domésticos no llega al 10\% ( $8 \%$ y $7 \%$ respectivamente), en Australia el $64 \%$ se dedica a fines domésticos, en Europa el $14 \%$ y en Estados Unidos el $13 \%$. El uso del agua para fines industriales es también muy diferente entre los continentes: África el 5\%, Asia el $9 \%$, Estados Unidos el $48 \%$ y Europa el $55 \%$, mientras que Australia sólo utiliza el $2 \%$ de su agua para la industria.

$Y$, si el agua está mal distribuida a nivel mundial y entre los sectores de producción, no menos mal distribuida está a nivel doméstico en los distintos países. Mientras África ha de conformarse con 47 litros /persona /día y Asia con 95 litros/persona / día, en el Reino Unido cada habitante utiliza cada día una media de 334 litros y el norteamericano 578 litros por día. Mientras en el Sahel el consumo medio de agua por persona y día es de menos de 30 litros, en algunas zonas de California este consumo sube hasta más de 3.500 litros diarios por persona, debido a los cientos de miles de piscinas y jardines privados.

\section{- Mala gestión}

Pero no sólo el agua está mal distribuida; la poca agua disponible para el uso humano se gestiona mal. El 50\% del agua de riego y del agua potable tratada se pierde por fugas en los sistemas de distribución, por evaporación o por filtraciones en los canales de distribución. De la que llega finalmente al consumo humano, una gran parte se degrada y poluciona por el uso masivo de productos químicos y metales pesados en la industria y por el uso de plaguicidas tóxicos y fertilizantes en la agricultura, así como por la falta, para un $40 \%$ de la población mundial, de redes de saneamiento y tratamiento de aguas residuales domésticas e industriales que se vierten directamente en ríos y lagos. A todo ello hay que añadir el despilfarro irracional que se hace del agua en los países más desarrollados tanto para fines de ocio (piscinas, campos de golf, etc.) como en el uso doméstico, para muestra basta un botón: una descarga de agua de nuestra cisterna del W.C. es igual a toda el agua que usa una persona del Tercer Mundo, por termino medio, en un día para beber, asearse, lavar y cocinar. 


\subsection{El agua como fuente de conflictos}

Este desequilibrio entre la oferta y la demanda de agua que acabamos de analizar es lo que muchos organismos internacionales y especialistas de instituciones privadas empiezan a ver como un potencial foco de serios conflictos en un no muy lejano horizonte temporal, especialmente cuando la demanda de agua de un país se pretende satisfacer a costa de la oferta de otro país, desviando las aguas de un río transfronterizo o construyendo en su propio país grandes presas y grandiosas obras hidráulicas sobre estos cauces, privando al país vecino del agua que necesita.

Teniendo en cuenta la oferta de los recursos hídricos disponibles en el mundo, la demanda de la población y el uso de la ciencia y las nuevas tecnologías, el Profesor Carlos A. Fernández-Jáuregui (2002), hidrólogo regional de la UNESCO, confeccionó el concepto de «estrés hidrológico», es decir el desequilibrio entre la oferta y la demanda de agua en una región determinada, con una población determinada y unos niveles tecnológicos también determinados, y los resultados fueron los siguientes:

CUADRO 3

Desequilibrio actual oferta-demanda de agua

\begin{tabular}{|c|c|c|c|c|}
\hline & Sin estrés & Bajo estrés & Estrés & Alto estrés \\
\hline \multicolumn{5}{|l|}{ NÚMERO DE PAÍSES } \\
\hline $\begin{array}{l}\text { Pueden hacer frente a una situación } \\
\text { determinada (confiabilidad) }\end{array}$ & 16 & 76 & 57 & 11 \\
\hline $\begin{array}{l}\text { Ejercen presión sobre los recursos } \\
\text { hídricos (uso/recurso) }\end{array}$ & 98 & 21 & 22 & 19 \\
\hline \multicolumn{5}{|l|}{ POBLACIÓN (MILLONES) } \\
\hline $\begin{array}{l}\text { Pueden hacer fente a una situación } \\
\text { hídrica determinada (confiabilidad) }\end{array}$ & 147 & 2.025 & 3.283 & 241 \\
\hline $\begin{array}{l}\text { Ejercen presión sobre los recursos } \\
\text { hídricos (uso/recurso) }\end{array}$ & 1.693 & 2.068 & 1.462 & 472 \\
\hline
\end{tabular}


Si miramos a los 160 países examinados por el autor vemos que sólo el 10\% puede hacer frente con confianza a un equilibrio entre oferta y demanda de agua, mientras que el restante $90 \%$ de los países sufrirán algún grado de estrés. Y, si volvemos la mirada a la población, vemos que, de una población de unos 5 mil millones, menos del 3\% de la población mundial pueden mirar el futuro de su agua con confianza y sin estrés, mientras que el $97 \%$ restante sufrirá algún grado de estrés al intentar satisfacer esta necesidad básica.

Al intentar evaluar lo que será la situación futura en el año 2025, cuando la población mundial se espera que haya crecido, al ritmo actual, en más de 2.500 millones, la situación se presenta crítica y preocupante, pues la inmensa mayoría de los habitantes de todos los continentes estará bajo un estrés más o menos grave al tener que hacer frente a sus necesidades de agua

CUADRO 4

Desequilibrio oferta-demanda de agua en 2025

\begin{tabular}{|l|c|c|c|c|}
\hline Población (en millones) & Sin estrés & Bajo estrés & Estrés & Alto estrés \\
\hline América del Norte & 30 & 330 & - & - \\
\hline América Latina & 15 & 480 & 200 & - \\
\hline Europa Occidental & 18 & 180 & 310 & 14 \\
\hline Europa Oriental & - & 65 & 18 & 20 \\
\hline África & 200 & 810 & 400 & 160 \\
\hline Oriente Medio & - & 45 & 300 & 40 \\
\hline China & - & 700 & 1.680 & - \\
\hline Sudeste asiático & - & 500 & 1.685 & - \\
\hline Pacífico & - & 26 & 122 & - \\
\hline
\end{tabular}

Con una población en continuo crecimiento presionando cada vez más sobre los limitados recursos hídricos del planeta, no parece exagerado decir que el siglo XXI será el siglo del agua, con casi la mitad dela población mundial sufriendo escasez de agua, poniendo en peligro la seguridad de muchos pueblos. En el año 2025 un 97\% de la población de más de ocho mil millones 
de personas sufrirá algún tipo de estrés sobre la obtención del agua que necesitará para consumo doméstico, agricultura y nuevas industrias.

Aunque raramenteel agua es la causa directa de un conflicto bélico, el agua puede ser un componente importante en los conflictos entre países especialmente en aquellas zonas donde el agua escasea; la poca cantidad disponible puede variar sensiblemente por una o dos sequías, y los países experimentan una gran presión demográfica y realizan un gran esfuerzo para su desarrollo socioeconómico.

En 1994, el Profesor Peter Gleick, del «Pacific Institute for Studies in Development, Environment and Security», publicó en la revista Environment un trabajo sobre los conflictos surgidos por temas del agua en los mitos, las mitologías y la historia de las primeras civilizaciones del Cercano Oriente desde los años 5.000 a 2.300 a.C.. El estudio Ilamó la atención de mucha gente, especialistas en distintos campos de historia, geografía, sociología, etc. quienes le empezaron a mandar información sobre este tipo de conflictos en las épocas más recientes. Y con esta información y su propio esfuerzo personal, en 2000 publicó otra cronología de conflictos sobre el agua desde el siglo VI hasta nuestros días recogiendo, sólo en el siglo XX, más de setenta conflictos. El Profesor Gleick clasifica estos conflictos por el agua en seis categorías:

1. Control de los recursos hídricos.

2. El agua como arma militar.

3. Agua como arma política.

4. Agua como arma terrorista.

5. Agua como objetivo militar.

6. Agua como instrumento de desarrollo.

Como apunta el mismo autor, estas clasificaciones con frecuencia se mezclan y pueden confundirse, pero en otros casos están claramente diferenciadas. Algunos ejemplos bastarán para entender esta clasificación, y para entender la importancia que tiene, o mejor, debería tener el agua en todos los esfuerzos nacionales e internacionales para construir un mundo más seguro y pacífico:

- 1938 (arma militar y objetivo militar): en China, Chiang-Kai-shek destruye los diques de contención del río Amarillo inundado los campos 
amenazados o ya conquistados por el ejercito japonés.

- 1940-45 (II guerra mundial; arma y objetivo militar): en Europa los pantanos, diques y obras hidráulicas fueron bombardeados regularmente tanto por los nazis como por los aliados.

- 1947 (arma política, desarrollo, y disputas sobre fuentes): la partición del subcontinente asiático entre India y Pakistán deja la cuenca del río Indo dividido entre los dos nuevos países, lo que afecta al potencial de desarrollo de los dos.

- 1948 (arma militar): las fuerzas árabes, en lucha con los judíos, corta el suministro de agua a Lerusalén Oriental.

- 1950 (arma y objetivo militar): las presas del río Yalu que sirven a Corea del Norte y China son bombardeados y destruidos.

- 1960 (objetivos militares): en Vietnam del Norte, los sistemas de irrigación y distribución de agua son bombardeados por los americanos.

- 1962 (arma política y militar): Paraguay y Brasil llegan casi a un enfrentamiento armado sobre el control de las aguas del río Paraná.

- 1971 (arma política y necesidad de desarrollo): la creación del nuevo Blangadesh crea tensiones con la India por las aguas del Ganges que fluyen en los dos países.

- 1969 (arma militar y política): Israel destruye los canales que llevan el agua del río Jordán a Lordania.

- 1970 (objetivo político y de desarrollo) Argentina, Brasil y Paraguay se enfrentan con ocasión de la construcción de la gigantesca presa de Itaipú.

- 1974 (arma política y militar): Irak amenaza bo mbardear la presa de alThawra.

- 1978 (objetivo militar): tropas de África del Sur entran en Angola para defender el complejo hidrológico de Ruacana.

- 1978 (desarrollo y arma política): Egypto y Etiopía llevan años disputando sobre las aguas del Nilo Azul, llegando a amenazas de guerra sobre este agua.

- 1982 (arma militar): Israel corta el suministro de agua a Líbano. 
- 1990 (arma militar y política y desarrollo): la construcción de la presa de Ataturk por Turquía, sobre el Eufrates, interrumpe el suministro de agua por varios días a Siria e Iraq. Turquía amenaza cortar el suministro de agua a Siria si este país ayuda a los kurdos.

- 1991 (desarrollo y control de aguas): el estado de Karnataka está enfrentado por años al Estado de Tamil Nadu, en la India, sobre el control del agua del río Cauvery.

- 1991 (objetivo militar): durante la guerra del Golfo, Irak destruye las plantas desalinizadoras de Kuwait, y Estados Unidos destruye los sistemas sanitarios y de distribución de agua de Bagdad.

- 1992 (objetivos militares): los serbios cortan el suministro de agua de Sarajevo, en Bosnia y Herzegovina.

- 1995 (arma política y militar): Ecuador y Perú se enfrentan por el control del agua del río Cenepa.

- 1997 (arma política y militar): Malasia amenaza con cortar el suministro de agua que da a Singapur.

- 1998 (terrorismo, arma política): en Turkmenistán la guerrilla amenaza con volar la presa de Kairakhum si sus demandas no son escuchadas.

- 1999 (terrorismo): en Zambia, la guerrilla destruye las canalizaciones de agua de Lusaka.

- 1999 (objetivo militar): Ia OTAN destruye el suministro de agua de Belgrado y bombardea los puentes sobre el Danubio.

- 1999 (terrorismo): en Timor del Este las milicias oponentes a su independencia arrojan cadáveres a los pozos de agua potable.

- 2000 (objetivo militar): Namibia, Botswana y Zambia presentan una querella ante la Corte Internacional de J usticia para resolver su contencioso sobre el uso de las aguas del río Chobe².

Pero no necesitamos ir al pasado para ver los conflictos que hoy mismo surgen, o pueden surgir en un futuro no muy lejano, por causa de la distribución de las aguas. La ONU considera que hoy hay más de 300 puntos calientes en el globo por posibles conflictos sobre recursos hídricos. Actualmente, de los 263 cauces de ríos que cruzan las fronteras de 145 países, y que

2 GleICK, P.H., ver versión actualizada de 2000 en: www.worldwater.org/conflict.htm 
representa el $60 \%$ del agua dulce del mundo, sólo en 153 casos hay algún tipo de acuerdo entre los países afectados. Los puntos más calientes en el tema del agua son, sin duda, los siguientes:

Oriente Próximo: dos tercios del agua que consume Israel viene de los territorios ocupados, mientras que más de la mitad de las instalaciones hídricas del mismo Israel están en territorios ocupados después de 1967. El problema del agua en el Próximo Oriente incluye Israel, Palestina, Siria, J ordania y Líbano todos dependiendo en mayor o menor medida del agua de los ríos que forman el Mar de Galilea, en especial el Jordán que nace en Líbano, entra en Israel, formando frontera con Siria, atraviesa el Mar de Galilea para ir a desembocar en el Mar Muerto. También ha habido tensiones entre Israel y Líbano por el proyecto de este país de control de las aguas del río Wazzani que aporta un cuarto de toda el agua que llega al Mar de Galilea, lo que ha hecho declarar al Presidente Ariel Sharon que el llevar a cabo este proyecto sería suficiente para declarar un «casus belli». Otro foco de posibles conflictos en esta parte del planeta es el norte de Turquía con el intento por este país de controlar los ríos Eufrates y Tigris para la producción de electricidad y para irrigación, con la gigantesca presa de Ataturk, a lo que se oponen Siria e Iraq. También ha habido problemas sobre el canal de Sharatal-Arab que partiendo de Iraq, desemboca en el Golfo Pérsico, formando frontera con Irán y Kuwait, y hay conflictos actualmente entre Egipto, Sudan y Etiopía sobre las aguas del Nilo.

En Asia los mayores focos de conflictos son las aguas del valle del Indo entre India y Pakistán y las aguas del Ganges y Brahmaputra entre Nepal, India y Bangladesh, y para el control de la parte alta del río Mekong por parte de Vietnam, Camboya, Laos y Tailandia. En Asia Central se enfrentan las poblaciones de Uzbequistán, Kazakhstán y Tajikistán sobre los ríos Amu Daria y Syr Daria, así como el Mar de Aral.

En África el río Chobe tributario del Zambesi se ha convertido en una fuente de tensiones entre Botswana, Mozambique, Zambia y Zimbabwe, y ha habido conflictos froterizos entre Mauritania y Senegal sobre el control del río Senegal.

En América del Norte tenemos los puntos calientes entre México y EEUU sobre el río Colorado, y en América del Sur los conflictos por las aguas del Paraná entre Paraguay, Argentina y Brasil.

En la misma Europa se han creado tensiones entre Hungría y Eslovaquia sobre las aguas del Danubio, lo que les ha llevado a presentar su caso ante la 
Corte Internacional de Justicia. Y en nuestro propia país tenemos ahora el conflicto entre regiones sobre el trasvase del Ebro.

Es obvio que se necesita, para evitar posibles conflictos, un marco jurídico internacional para regular las relaciones entre países que comparten fuentes y cauces de agua dulce, pero esto es muy difícil, como veremos en el apartado siguiente, pues supone que los países implicados han de renunciar a parte de su soberanía sobre las aguas de su territorio y han de sacrificar parte de los beneficios económicos que podrían sacar de su explotación.

\section{El Derecho Internacional de Aguas}

La necesidad de algún tipo de regulación del uso de las aguas de los ríos que fluyen por distintos países y lagos que cruzan fronteras nacionales se ha sentido desde la antigüedad, y la falta de esta regulación ha sido, con frecuencia, la causa desangrientos enfrentamientos armados, prevaleciendo siempre el más fuerte. A falta de una legislación internacional aceptada por los países implicados en las disputas sobre las aguas, han prevalecido los precarios acuerdos bilaterales voluntarios que cualquier cambio de gobierno puede decidir romper. Desde mediados del siglo XX numerosos expertos de las distintas ramas del saber y diversos organismos nacionales e internacionales se han preocupado por el problema del agua en el mundo y se han organizado innumerables simposios, seminarios, conferencias nacionales e internacionales para discutir el problema del agua y ver las posibilidades de crear un marco jurídico que regule las relaciones hidráulicas de los distintos países. Pero, hasta ahora, poco se ha alcanzado en esta materia.

Varias son las causas por las que es difícil crear un cuerpo legal internacional sobre las aguas: Ios problemas en cada cuenca son distintos y es casi imposible imponer reglas legales para todos; las leyes aparecen demasiado controvertidas para poder ofrecer una solución a todos los problemas del agua; los países no están dispuestos a ceder parte de su soberanía sobre las aguas nacionales a favor de los otros estados que también las utilizan, ni están dispuestos a sacrificar los beneficios económicos que de las aguas nacionales se derivan, a favor de otros estados vecinos. Finalmente, no hay un poder coercitivo internacional que pueda hacer cumplir esta legislación y pueda sancionar al estado que la incumpla. La falta de esta regulación internacional del uso de las aguas lleva a que se haga un uso irracional de las cuencas hídricas con perjuicio del ecosistema, graves perjuicios económicos para zonas de cultivo necesitadas de agua para riego, y violación del derecho 
a un suministro de agua adecuado para las poblaciones ribereñas.

La legislación del agua a escala internacional puede cubrir todos los aspectos de gestión y desarrollo de los recursos hídricos, pero para ello es necesario: a) que se determinen claramente todas las partes que tienen intereses en el agua y las bases jurídicas o consuetudinarias de estos intereses; b) una vez determinados qué usos deben ser permitidos, debe fijarse un marco de reparto de estos usos que debe ser flexible, predecible y capaz de hacer que se cumpla; y c) deben crearse mecanismos para hacer que se cumplan las reglas establecidas, para evitar disputas antes de que surjan y para encontrar soluciones equitativas a aquellas que no han podido evitarse. Con todo, varios esfuerzos se han hecho para desarrollar este marco jurídico para el uso de las aguas transnacionales. Aquí vamos a resumir los más importantes.

1966. Los Principios de Helsinki. Estas normas provienen de un estudio efectuado por la Asociación de Derecho Internacional y tienen el respaldo de las Naciones Unidas, y en marzo de 1992 fueron transformadas, por encargo de la Comisión Económica de la ONU para Europa, en la «Convención de Helsinki» o "Convenio sobre protección y utilización de los cursos de agua transfronterizos y de los lagos internacionales", con lo cual existe ahora un marco legal por lo que respecta al manejo de los recursos hídricos que comparten diferente países europeos.

El Convenio tiene tres partes. I. Disposiciones aplicables a todas las partes que incluye: prevención y control de conflictos, vigilancia, investigación y desarrollo, intercambio de información; II. Disposiciones relativas a los estados ribereños e incluye: cooperación bilateral y multilateral, consultas, vigilancia, investigación y evaluación conjuntas, intercambio de información, sistemas de alerta y alarma, asistencia mutua e información publica; III. Disposiciones Institucionales y Finales sobre organización de las comisiones, enmiendas al Convenio, entrada en vigor, etc.

En resumen, este Convenio supone:

- Una renuncia por cada estado que comparte una cuenca, a su soberanía absoluta sobre sus aguas, reconociendo los intereses y derechos de otros países vecinos, de manera que cada estado, teniendo el control soberano de todas las partes de su territorio, no puede ejercerlo sobre territorio situado en una cuenca hidrográfica compartida internacio- 
nalmente, sin examinar los efectos en los demás estados de la cuenca.

- Reconocimiento de que cada estado de la cuenca tiene derecho a una parte razonable y equitativa del agua de la cuenca y que cada estado debe buscar el beneficio máximo en el uso de las aguas, con el perjuicio mínimo para los demás estados de la misma cuenca.

- Obligación de indemnizar a otros países cuando se perjudican sus intereses.

- Análisis de costos y beneficios en la planificación y ejecución de un proyecto hidrográfico, con el objetivo de su funcionamiento sostenible.

- Obligación de mantener informados a los estados vecinos de cualquier actuación sobre la cuenca compartida con ellos.

- Creación de comisiones de consulta y arbitraje para resolver conflictos entre estados que comparten las mismas cuencas hidrográficas.

Las normas de la Convención son muy flexibles, dejando mucho espacio para que esas puedan adaptarse a situaciones concretas dependiendo del tamaño de la población, el impacto medioambiental, los beneficios y perjuicios causados, etc.

1991. Los Principios de Copenhague. La base del marco normativo internacional actual para el manejo de recursos hídricos integrados se estableció en una consulta internacional celebrada en Copenhague en 1991. Se aprobaron en general dos principios importantes: según el primero, los recursos hídricos y terrestres deben ser administrados en el plano más bajo que resulte apropiado, es decir, lo más cerca posible a los que los usan. El segundo principio ya anuncia claramente por primera vez lo que hoy se ha convertido en el debate fundamental sobre el agua; en Copenhague se afirmó rotundamente que el agua debe ser considerada un bien económico, con un valor que refleje su uso potencial más valioso.

1992. La Conferencia de Dublín. En la conferencia preparatoria de la CNUMAD (Conferencia de las Naciones Unidas para el Medio Ambiente y el Desarrollo), celebrada en Dublín, los principios pasaron a ser cuatro:

1. El agua es un recurso limitado y vulnerable, necesario para mantener la vida, el desarrollo y el medioambiente. Un manejo efectivo debe vincu- 
lar el uso total de tierras y aguas de toda una cuenca hidrográfica o un acuífero subterráneo.

2. El aprovechamiento y el manejo del agua debe basarse en un método participativo en el que intervengan los planificadores y los usuarios a todos los niveles y las decisiones deben tomarse en el nivel más bajo que sea conveniente.

3. Es necesario tener en cuenta el hecho con frecuencia olvidado de que las mujeres desempeñan un papel crucial por lo que respecta al abastecimiento, manejo y protección del agua.

4. El agua tieneun valor económico en todos sus usos que compiten y debe ser reconocida como un bien económico.

1992. La Conferencia de las Naciones Unidas Sobre el Medioambiente y el desarrollo (Río de Janeiro)

En esta Conferencia de la CNUMAD, celebrada en Río de Janeiro, las cuestiones del agua fueron tratadas en un capítulo especial del Programa 21, y los cuatro principios propuestos por la conferencia preparatoria y mencionados más arriba, pasaron a ser las directrices de dicho capítulo, en el que se incluyeron también recomendaciones referentes a otras medidas

1997. La Convención sobre el Uso de Cursos de Aguas Internacionales para fines distintos a la navegación

Ya en 1970, la Asamblea General de la ONU encargó a su comisión de Derecho Internacional que elaborase un Proyecto de Acuerdo Internacional de Cuencas, pero desde el inicio de su trabajo quedó claro que muchos países no estaban dispuestos a someterse a limitación alguna en cuanto al uso de sus aguas. La «convención marco»presentada en 1994 sólo cumplía estándares mínimos en cuanto al uso sostenido y la necesidad de minimizar los daños que podrían producirse a otros países, pero no decía nada de los instrumentos de prevención de conflictos y mecanismos para su solución. Después de arduas y acaloradas discusiones, el 21 de mayo de 1997 se aprobó por una pequeña mayoría el texto de la "Convención sobre el derecho del uso de cursos de agua internacionales para fines distintos a la navegación", al que posteriormente cada estado individualmente tenía que adherirse, cosa que muy pocos han hecho hasta ahora. 
Quizás lo más importante de este Convenio se encuentra en su Parte Introductoria en la que se declara como principio básico, el que los estados, dentro de sus propias fronteras y, más allá de las mismas, han de utilizar los cursos de agua transfronterizos de forma equitativa y razonable, lo que supone tomar en consideración:

- Los factores naturales geográficos, hidrográficos, hidrológicos, climáticos y ecológicos.

- Las necesidades sociales y económicas de los estados implicados.

- La población dependiente de estos cursos de agua.

- Los efectos del uso por un estado de estos cursos de agua sobre los otros estados implicados.

- Los usos actuales y potenciales de estos cursos de agua.

- La conservación, protección, desarrollo y uso económico de estos cursos de agua y el coste de asumir estas responsabilidades.

- La disponibilidad de otras alternativas, de similar coste económico, al uso existente o previsto para el futuro de estos cursos de agua.

- La obligación de cada estado de tomar las medidas necesarias para evitar en el uso de un curso de agua posibles daños a otros estados implicados, y de tomar, en colaboración con los otros estados, todas las medidas necesarias para minimizar estos daños llegando, si es necesario, a un acuerdo sobre compensaciones.

La Parte III se refiere a los planes que pueda tener un estado sobre el uso y gestión de unos cursos de agua. Los estados se obligan, en base a su igualdad soberana, integridad territorial, benéfico mutuo y buena fe, a colaborar en la solución de los problemas que puedan surgir y a un intercambio regular de información sobre todos los aspectos técnicos y económicos del curso de agua que comparten. $Y$, en caso de conflicto, se intentará resolverlo tomando como punto prioritario las necesidades de las poblaciones humanas. Cada estado, antes de tomar medidas sobre el curso de agua que puedan afectar a otros estados, comunicará estas medidas y escuchará sus opiniones sobre los efectos previstos, especialmente sobre la población y el entorno ecológico.

La Parte IV trata de la protección, preservación y gestión de los cursos de agua. Los estados se obligan individualmente y, a ser posible, conjuntamen- 
te, a preservar el ecosistema de los cursos de agua que comparten. Una obligación primordial en este contexto es el de la prevención, reducción y control de la contaminación de estos cursos de agua internacionales. Los estados han de desarrollar prácticas para reducir la contaminación de las aguas desde sus fuentes hasta su desembocadura, preparar una lista de sustancias químicas que esté prohibido verter en las aguas, así como prohibir la introducción denuevas o extrañas especies de animales y plantas.

La Parte $V$ trata de las consecuencias dañinas para las poblaciones y las situaciones de emergencia que pueden ocasionar los cursos de agua internacionales, como inundaciones, enfermedades transmitidas por el agua, erosiones, salificaciones, desertizaciones y sequías. En todos estos casos los estados, individualmente y, si es posible, conjuntamente, han de tomar todas las medidas pertinentes para prevenir o mitigar los efectos de estas situaciones.

La Parte VI trata de una variedad de casos en los que los cursos de agua internacionales tienen un particular protagonismo, como la obligación de proteger en caso de conflicto bélico, según el Derecho Internacional, las fuentes e instalaciones de agua para la población, la no discriminación por razón de nacionalidad o residencia. Finalmente, el Art. 33 desarrolla toda una normativa detallada sobre la solución de conflictos entre estados que utilizan los mismos cursos de agua, y este artículo está completado con un largo Anexo sobre el arbitraje para la solución de estos conflictos.

La importancia de esta Convención de las Naciones Unidas está en que ha ofrecido a los estados un marco para definir las relaciones que deben existir en los países que comparten cursos de agua transnacionales, y ofrece una serie de directrices procedimentales para que los estados puedan desarroIlar su propia legislación sobre el tema, y ofrece también un marco de referencia para la solución pacífica de los conflictos que puedan surgir sobre cursos de agua transnacionales. Una limitación de esta Convención es el poco espacio que dedica a los temas de protección del medioambiente.

1998. La Conferencia Internacional de Petersberg (Alemania) en su declaración final introduce tres puntos importantísimos para la gestión del agua en países en vías de desarrollo: primero, la Conferencia pone en estrecha relación el desarrollo de los pueblos y la disponibilidad deagua de los mismos; segundo, matiza el concepto de agua como bien económico afirmando que es un bien tanto económico como social; $y$, tercero, insiste en la participación de los individuos y las organizaciones privadas en la gestión del agua. 
Los Puntos esenciales de la Declaración Final son:

- El agua es un catalizador de la cooperación.

- El agua es un bien económico y social. Su uso debellevarse a cabo sobre la base de estudios de impacto ambiental y de costos/beneficios.

- El aprovechamiento debe realizarse en el marco de la cooperación política regional, también con la participación del sector privado y las ONG.

- Un instrumento para esta cooperación pueden ser comisiones internacionales de cuenca, cuya creación debe ser fomentada.

- Las medidas generadoras de confianza y el fortalecimiento de los instrumentos legales en la política hidrológica crean un clima propicio a la cooperación.

- Deben realizarse estudios de casos sobre ejemplos de gestión de aguas transnacionales.

- Deben fomentarse la transmisión y propagación de estos conocimientos entre políticos y expertos en cuestiones hidrológicas.

1998. El Informe del Grupo de Expertos del Consejo Económico y Social de la ONU. Harare (Zimbabwe). Este Informe tiene especial importancia en el tema que nos ocupa pues por primera vez reconoce explícitamente el concepto de «soberanía restringida en el uso de las cuencas transnacionales»y contiene importantes recomendaciones para el desarrollo del concepto de «Gestión Integral de Recursos del Agua».

2000. El Segundo Foro Mundial del Agua de la Haya (en 1997 se había celebrado ya el Primer Foro Mundial del Agua en Marraquesh). Del 17 al 22 de marzo de 2000 se reunieron en La Haya más de 6.000 personas junto con 159 delegados para analizar los retos del agua en el nuevo siglo XXI. Muchas fueron las ponencias que se presentaron, no todas de gran utilidad, pero de todas ellas se pueden sacar algunas ideas básicas:

- La gestión de los cursos de agua internacionales debe regirse, no tanto por la idea de «soberanía limitada», como hasta entonces se había afirmado, sino por un verdadero espíritu de cooperación e interdependencia efectiva. 
- Se insistió en la necesidad de desarrollar un marco jurídico más detallado para fortalecer la seguridad del agua a nivel local, nacional e internacional, y se sugirió que para el año 2015 tendría que haber unos mecanismos institucionales desarrollados para compartir los cursos de agua en todas las cuencas ribereñas del mundo.

- La reunión insistió en la necesidad de identificar los principales retos que se plantean para conseguir una efectiva seguridad de agua a nivel mundial para poder: satisfacer las necesidades básicas, asegurar una adecuada oferta de alimentos, proteger los ecosistemas, compartir recursos hídricos, gestionar los riesgos, reconocer el valor económico del agua, gestionando sabiamente el recurso agua.

- Los gobiernos deben trabajar con todas las partes con intereses en el agua, fijando sistemas de compensación por los daños causados a los recursos hídricos por actividades peligrosas.

2003. El Tercer Foro Mundial del Agua de Kyoto (Kyoto 16 marzo 2003).

En el Segundo Foro Mundial del Agua se pidió al «Water Action Unit», compuesto por expertos internacionales en temas de agua, que preparase un documento que sirviese de base para el próximo Foro Mundial del Agua a celebrar en Kyoto en 2003. Después de dos años de trabajo el «Water Action Unit» tenía preparado un informe basado en un inventario de 3.000 posibles acciones $^{3}$ a desarrollar en los distintos campos de planificación, preparación e implementación de investigación aplicada y estudios de casos, campañas de sensibilización, políticas y reformas institucionales y legislativas, dirigido todo a mejorar la gestión del agua a todos los niveles: local, nacional e internacional. El Informe está dividido en dos partes:

Ia Parte: «Evaluación de los retos y comienzo del cambio» que expone las necesidades más urgentes en términos de una buena gestión del agua:

- Reconocimiento de los múltiples valores del agua.

- Gestión del agua más eficaz y eficiente.

- Reforzamiento de la cooperación internacional.

3 Estas acciones pueden consultarse en INTERNET en la página www.worldwatercouncil.org/ search-actions.php 
- Promoción de la igualdad de género en los procesos de toma de decisiones en materia del agua.

- Gestión del problema de las variaciones climáticas y su impacto sobre el cambio climático.

- Financiación del desarrollo vinculado al agua.

IIa Parte: «Cambios que se están dando en las principales regiones del mundo y las necesidades especificas en algunos sectores»: agua y sanidad, energía, salud agricultura, biodiversidad y ecosistemas:

- Garantía de un acceso sostenible al agua y a sistemas de saneamiento.

- Respuesta a las respectivas demandas en los sectores del agua y la energía.

- Mejora de los resultados en el campo de la salud con nuevos proyectos y una mejor gestión del agua.

- Incremento de la producción agrícola a la vez que se protegen las fuentes de agua para consumo humano y para los ecosistemas.

- Asegurar suficientes cantidades de agua necesaria para mantener la biodiversidad y los ecosistemas.

A los seis meses de la celebración de la Conferencia Internacional sobre Desarrollo Sostenible celebrada en J ohannesburg, los días del 16 al 23 de marzo del 2003 se celebró en Kyoto y otras dos ciudades japonesas, el Tercer Foro Mundial del Agua, con la presencia de unos 20.000 participantes de 182 países y 43 organismos internacionales. Tenía como objetivo básico el aumentar la conciencia de los problemas del agua, discutir las adecuadas políticas de agua y asegurar la participación activa de todos en la consecución del objetivo del milenio de las Naciones Unidas de «reducir a la mitad el número de personas sin acceso directo a agua potable y servicios de saneamiento para el año 2015».

En el transcurso de las 337 sesiones y las 1.500 ponencias del foro se discutieron todos los posibles aspectos del agua en el mundo moderno: agua y cambio climático, diversidad cultural, energía, saneamiento, higiene y problemas de contaminación, participación de género, alimentación y medio ambiente, transporte, inundaciones, financiación publica y privada, agricultura y alimentos, ciencia, nuevas tecnologías y gestión, pobreza, salud, grandes obras de infraestructura, educación y paz regional y mundial. El Foro 
se inició con un discurso, en ausencia, del Presidente de Francia Jacques Chirac y terminó con una Declaración Ministerial de 16 páginas dividida en seis apartados: 1. Política General de Agua, 2. Gestión de recursos hídricos y participación en sus beneficios, 3. Agua potable y saneamiento, 4. Prevención de la contaminación del agua y conservación de los ecosistemas, 5. Reducción de desastres naturales y gestión en situaciones de riesgo. Pero hay que decir que todas estas declaraciones fueron tan vagas y generales que muchos críticos las consideraron un «modelo de vaguedades». La mayoría de las ideas presentadas por estos ilustres personajes ya se habían oído una y otra vez en foros y conferencias similares, no añadiendo nada nuevo a los principios generales. Los ministros allí presente no pudieron o no quisieron establecer planes concretos ni ofrecer ayudas económicas concretas para resolver el problema del agua en el mundo. Hay que señalar también, como algo que muestra el talante de este Tercer Foro Mundial del Agua, que en ningún documento o discurso oficial se hizo referencia a lo que sería, el mismo año, la declaración de noviembre del 2003 del Consejo Económico y Social de las Naciones Unidas sobre el «agua como derecho básico de la persona».

Sin duda alguna, el tema que más controversia suscitó fue el de la llamada a la cooperación entre los sectores públicos y privados para la financiación de los proyectos de abastecimiento y saneamiento de agua. Ya el Presidente Chirac, después de decir en su discurso inaugural que «el agua es un bien público y nadie puede apropiarse de él», a continuación, al reconocer que una política de agua eficaz requiere de medios considerables, afirmaba categóricamente que estos fondos «procederán sobre todo del sector privado» y termina con un patriótico «Francia invita a sus inversores a desarrollar su presencia en el sector del agua». La Declaración Ministerial insiste también en la necesidad de crear un contexto, en el campo de la gestión del agua, que facilite la inversión privada: «debemos explorar, dice, todas las posibilidades de financiación, incluida la privada, y crear mecanismos público-privados de colaboración según los casos». Pero no es de extrañar esta postura a favor de la privatización del agua, si se piensa que el Foro Mundial del Agua está promovido por el Consejo Mundial del Agua, un organismo privado al que pertenecen además de representantes de las Naciones Unidas y el Banco Mundial, Ias multinacionales del agua y la Asociación Internacional de Aguas Privadas.

Los debates sobre el Informe «Financiando el agua para todos» fueron los más agitados del Foro. Los ponentes pro-privatización del agua fueron interrumpidos continuamente por grupos anti-privatización como «World 
Water Warriors», los «Public Services International», el «ndigenous Network» y el «nternational Rivers Network» que se presentaron en el Foro con banderas, cintas en la cabeza y distintivos en el pecho y repartiendo pegatinas, y tomando los micrófonos en cada sesión importante para condenar la privatización del agua y dar a conocer los efectos dañinos que ésta puede tener para muchas comunidades, para denunciar la corrupción de algunas multinacionales del agua, y para acusar al Fondo Monetario Internacional y al Banco Mundial por su falta de responsabilidad y transparencia frente a las comunidades consumidoras del agua.

El tema de la privatización o no privatización del agua es tan candente hoy que vale la pena analizarlo con cierto detalle en el próximo apartado.

\section{El agua ¿un bien económico o un derecho fundamental?}

\subsection{El agua un bien económico}

«Todo tiene un precio», este parece ser el lema que rige todas las relaciones nacionales e internacionales en el presente mundo neoliberal. Todo se puede valorar monetariamente, todo se puede comprar y vender. Todo entra en el mercado para ser apropiado por el mejor postor. Los arboles, los animales todos, los ríos, los mares, el agua para beber, un día quizás hasta el aire, todo entra en el gran juego del mercado de la oferta y la demanda. Donde hay una demanda, sea del tipo que sea, siempre habrá al guien que pueda aprovecharse y enriquecerse ofreciendo los medios para satisfacer esta demanda. $Y$ cuanto mayor sea la demanda mayor será la rentabilidad de los bienes y servicios privados que puedan satisfacerla. Ya no quedan espacios comunes, todo, según el neoliberalismo debe ser apropiado por manos privadas y gestionado con el único criterio de rentabilidad económica. El problema del agua es, según este pensamiento, un problema de mala gestión y despilfarro de un bien escaso insustituible con unos precios ridículamente bajos. Hay que someter el agua a las rígidas reglas de la demanda y la oferta que serán las que fijarán el justo precio. Las infraestructuras de distribución y potabilización del agua han de pasar de manos públicas, sinónimo de ineficacia y burocracia, a manos privadas que son las que pueden hacerlo con eficiencia y mínimos costes de explotación. El Banco Mundial y el Fondo Monetario Internacional, junto con las grandes empresas transnacionales, están totalmente de acuerdo en esto: el agua es un bien económico y como tal debe 
tratarse, buscando siempre la máxima rentabilidad con los mínimos costes.

El agua -dicen estos organismos públicos y privados- debido principalmente al crecimiento de la población mundial, se ha convertido en un bien escaso e insustituible, sujeto a una posible apropiación y, como tal, en un bien económico cuyo precio ha de estar sujeto, como cualquier otro bien económico, a las reglas de la oferta y la demanda. El enorme despilfarro en el uso y gestión del agua es debido al hecho de que, hasta ahora, el agua ha sido considerada como un bien social más que como un bien económico. Ello ha mantenido artificialmente bajo el precio del agua y ha fomentado un uso negligente, derrochador e ineficaz, muy particularmente en la agricultura, que utiliza el $70 \%$ de toda el agua dulce disponible en el mundo, y en el hogar. Según estos organismos, los regímenes de propiedad privada en la construcción y gestión de infraestructuras de distribución y potabilización de agua, y de saneamiento, resultan más eficientes y rentables que los sistemas de propiedad pública en manos, sean nacionales, estatales o municipales.

Que el agua es un bien económico muy apetitoso para las empresas multinacionales lo muestra el hecho del nacimiento de grandes empresas multinacionales especializadas en la gestión del agua en muchas partes del mundo. Los dos grandes gigantes del agua en el mundo son Générale des Eaux (del grupo Vivendi) y Suez-Lyonnaise des Eaux; la primera, con el control de un $36 \%$ del mercado mundial del agua y un volumen de negocios de 7.100 millones de dólares, y la segunda, con el $22 \%$ de cuota de mercado internacional y un volumen de 5.100 millones de dólares, están presentes en 30 ciudades de 16 países, incluida nuestra ciudad condal través de «Aguas de Barcelona»; estas dos juntas son responsables del abastecimiento de agua para 140 millones de personas, mientras que el tercer gigante francés del agua, SaurBouygues, acapara el $16,5 \%$ del mercado mundial abasteciendo a 34 millones de personas especialmente en países en vías de desarrollo como Costa de Marfil, Malí o Senegal. Otras importantes empresas multinacionales del agua son Bechtel Corporation que gestiona más de 19.000 proyectos de agua en 140 países, RWE, compañía americana que unida a la británica Thames Water, sirve a unos 23 millones de hogares y controla el $18 \%$ del mercado internacional, y a todas estas hay que añadir los gigantes del agua embotellada, NESTLÉ y DANONE como números uno y dos mundiales en este campo. En todos estos casos la empresa privada asume las responsabilidades de gestión de un servicio público y el control de un bien común esencial. La empresa privada fija los precios y, en cierta manera, decidequién puedeutilizar el agua y en qué cantidad según su capacidad de «compra» de este bien. 
Pero realmente ¿puede el agua considerarse un bien económico y puede el precio del agua dejarse a los vaivenes de la oferta y la demanda? Desde el punto de vista puramente teórico esto es más que dudoso, y desde el punto de vista político y social esta postura es totalmente rechazable.

\subsection{Argumentos teóricos en contra de considerar el agua un bien económico}

Tres podrían considerarse los caracteres fundamentales de un bien económico y ninguno de los tres parece poderse aplicar al agua como tal, pero sí, desgraciadamente a la cantidad de agua disponible para ciertos grupos en ciertos lugares del planeta. Estos caracteres son Escasez, Apropiación y Sustitución.

Escasez. Para algunos autores lo fundamental para que algo pueda considerarse un bien «económico»es que ha de ser escaso y, en este sentido el aire no puede considerarse un bien económico porque hay abundancia ilimitada para todos, no es escaso, aunque quizás un día el aire puro sea un bien escaso por el quetengamos que pagar. El agua en el planeta tierra ¿es un bien escaso y, por tanto, un bien económico? Como ya hemos visto, aunque sólo una mínima parte del agua del planeta es agua dulce disponible para el consumo humano, los expertos insisten en que esta mínima cantidad bien gestionada sería suficiente para abastecer a una población mundial el doble de la actual. Además, con los nuevos avances tecnológicos, no es absurdo pensar que las aguas marinas podrán un día ponerse al servicio del hombre para su consumo directo y para la irrigación de los campos y para los animales. Por tanto, que haya escasez 0 abundancia de agua, que sea un bien económico «escaso »o un bien social al que tengan acceso todos los seres humanos, no depende del volumen de agua existenteen el planeta, sino de la decisión de los mismos seres humanos. El agua en el mundo no es escasa y, por tanto, como tal no puede considerarse un bien económico, pero sí es escasa, y a veces mortalmente escasa, en ciertas regiones del planeta, convirtiéndose en ellas en un bien económico muy apetitoso para satisfacer toda clase de ambiciones políticas o económicas. El decidir de antemano que el agua es un bien económico escaso, puede alentar a intereses económicos a mantener artificialmente esta escasez para poder aumentar sus beneficios. Una forma clara de mantener esta escasez artificialmente es reduciendo las inversiones para desarrollar formas de almacenamiento y distribución del agua o para perfeccionar nuevas técnicas de desalinización de las aguas marinas, lo que resolvería el problema de escasez de agua al menos en todos los pueblos de las costas. 
Apropiación. Otro elemento distintivo de un bien económico es que puede ser apropiado, es decir, que su oferta puede ser controlada. El aire, al menos por ahora, no puede considerarse un bien económico pues nadie puede controlar su oferta apropiándose del mismo. El agua, como tal, tampoco debería considerarse un bien económico, pues, como hemos dicho, hay suficiente agua en el planeta tierra para satisfacer las necesidades de todos los hombres, animales y plantas que lo habitan, sin que nadie tenga la necesidad de apropiarse de ella. Pero, en la práctica, en un lugar determinado, en un momento determinado, el agua puede ser escasa y por tanto puede ser $y$, de hecho, a través de la historia lo ha sido, apropiada por unos pocos, convirtiéndola en un bien económico, que han utilizado como instrumento de poder sobre los que no tienen acceso a ella. Convertir el agua en un bien económico sujeto a posible apropiación por unas manos privadas que puedan controlar su suministro, es entregarles el control de las vidas de las gentes que necesitan esta agua para su supervivencia.

Sustitución. Cualquier libro básico de economía explica el Principio de Sustitución como elemento esencial parafijar el precio deun bien económico. Este principio viene a decir lo que to do el mundo ya sabe: que el precio de un bien será determinado en gran parte por la existencia de sustitutos a este bien; cuanto mayor sea el número de sustitutos de un bien, manteniendo todos los otros elementos iguales, menor será su precio y, por el contrario, cuanto menor sea el número de sustitutos para este bien, mayor será su precio. El aumento del precio de un bien aumenta la demanda de sus sustitutos y, por el contrario, la disminución del precio de un bien reduce la demanda de sus sustitutos. La demanda de un bien varía directamente con los precios de sus sustitutos. ¿Qué pasa, entonces, si un bien no tiene sustituto alguno? Entonces su precio puede ser infinito. Y este es el caso del agua. Un hombre muriéndose de sed estaría dispuesto a dar toda su fortuna por un vaso de agua. Ahora bien, ¿se puede permitir el dejar en manos privadas, como otro bien económico cualquiera, el control de un bien esencial para la vida del hombre, que no tiene sustituto alguno? Asusta pensar que una empresa privada, para aumentar sus beneficios, pueda aumentar el precio del agua hasta niveles que los pobres no puedan pagar, como se ha dado el caso alguna vez, o que pueda cortar el suministro de agua de una familia porque no puede pagar la factura mensual. Un bien esencial, sin sustituto alguno, no puede dejarse en manos privadas. Es responsabilidad de los poderes públicos, sea el estado, el municipio u otra organización social, el asegurarse de que todos los ciudadanos pueden disfrutar de este bien esencial. 
5.3. Argumentos políticos y sociales en contra de considerar el agua un bien económico

El carácter irreconciliable de las posturas de los que defienden el agua como bien económico que debe privatizarse y los que defienden el agua como derecho fundamental que no puede dejase en manos privadas se vio, como ya hemos mencionado, en la cumbre del Agua de Kyoto. Con pancartas de «Agua es vida», «El agua es del pueblo»0 «Bienvenidos a la mafia mundial del agua», miles de representantes de grupos intelectuales y populares y ONG recibieron a los delegados de aquel Foro Mundial del Agua. La organización «Friends of the Earth Internacional" (FOIE) presentó un Informe titulado «Agua y J usticia para Todos: Resistencia global y local al control y cosificación del agua», y mientras los delegados del Foro defendían unánimemente la necesidad de tratar el agua como un bien económico sujeto a las reglas del mercado y cuyo precio tenía que ser marcado por la relación ofertademanda, en varios lugares del mundo como Florencia, Nueva Delhi, Nueva York y Cota, en Brasil, se organizaron Foros alternativos defendiendo todo lo contrario: que el agua ha de tratarse como un derecho humano y un bien común cuya gestión, bajo control público, ha de ser equitativa socialmente y sostenible desde el punto de vista medioambiental. En todos estos grupos se insistió que un bien que es un «derecho fundamental de la persona» no puede estar en manos de aquellos que creen que este bien es meramente un «bien económico»con el que se puede sacar un beneficio. Convertirlo en un bien económico es propiciar la creación de verdaderos monopolios que controlan un bien esencial para la vida. La privatización del agua tiende a favorecer la implantación de proyectos caros y de una tecnología sofisticada lo que aumenta la dependencia económica de estos países pobres e ignora los proyectos y formas de desarrollo locales realizados con la participación de las comunidades locales que así pueden mantener un cierto control sobre un bien esencial para su supervivencia. Los representantes argentinos mostraron, además, el fracaso total que fue el experimento de la empresa privada «Aguas Argentinas», pero el caso que más impactó a los participantes fue el de Cochabamba en Bolivia. El gobierno boliviano había concedido por 40 años un contrato de gestión de todas sus aguas a la empresa «Aguas del Tunari» subsidiaria de la norteamericana Bechtel Corporation. Bajo este nuevo contrato, el precio del agua subió un $200 \%$. De repente familias con unos ingresos de unos $100 \$$ al mes tenían que pagar una factura del agua de $20 \$$ y, si no lo podían pagar, se les cortaba el suministro de agua a sus casas. Los campesinos de Cochabamba durante cinco meses se lanzaron a las calles 
a protestar contra esta privatización. Hubo enfrentamientos con la policía con el saldo de dos muertos e innumerables heridos. Finalmente, el gobierno boliviano tuvo que rescindir el contrato con la Bechtel Corporation que pide ahora una indemnización de 25 millones de dólares por daños y perjuicios. En otros países de Latinoamérica, como Paraguay, Uruguay, Nicaragua y Colombia está ganando terreno el movimiento anti-privatización del agua.

Ya en el marco del Foro Social Mundial de Porto Alegre en 2002 se aprobaron una serie de «principios, creencias y valores sobre el agua» que podemos resumir así:

1. El agua dulce de la Tierra pertenece a toda especie viviente y no debe ser tratada como un producto, no debe ser comprada, vendida ni comercializada para producir un beneficio cómo si fuera un bien económico.

2. Este agua es un derecho fundamental del hombre y un derecho para toda la especie viviente. Dicho derecho debe ser salvaguardado por los poderes públicos y las instituciones, por el derecho nacional e internacional. El derecho de disponer de la cantidad y calidad suficientes para la vida (de 40 a 50 litros/día /persona) es un derecho justo, inalienable, individual y colectivo...

3. El agua es un recurso natural que debe ser utilizado de manera sustentable para el bien común de nuestras sociedades y del medio entorno natural.

4. El agua es esencial para la seguridad de nuestras comunidades y sociedades. Por esta razón, su propiedad, encargo y entrega pertenecen al dominio público. No se puede tener confianza en el sector privado para defender este interés público.

5. Las políticas de gestión del agua deben asegurar la equidad social como la equidad de género, la salud pública y la equidad con respecto al medioambiente.

\subsection{El agua, un derecho fundamental}

Pero ¿es realmente al agua un derecho humano fundamental, como se afirma categóricamente en Porto Alegre? Dicho en otras palabras: ¿tiene todo ser humano el derecho legal a exigir un mínimo de agua para cubrir sus necesidades básicas y, por tanto, tiene el Estado la obligación de suministrar 
este agua cuando hace falta? La respuesta a esta pregunta es importante porque una respuesta afirmativa implica que este derecho debe materializarse en una legislación nacional e internacional que obligue a los poderes públicos a crear las condiciones necesarias para el disfrute de este derecho fundamental, y a poner en práctica medidas punitivas contra aquellos que ponen obstáculos de cualquier clase al disfrute de este derecho.

El principal argumento para defender el derecho al agua es que esta es la condición «sine qua non» para el disfrute de otros derechos fundamentales reconocidos explícitamente en varios documentos internacionales ratificados por la mayoría de los gobiernos del mundo. Ninguno de las grandes convenios internacionales mencionan explícitamente el agua como un derecho fundamental, pero todos proclaman otros derechos cuyo disfrute sería absolutamente imposible sin el agua.

La Declaración Universal de los Derechos Humanos declara en su art. 25 que «Toda persona tiene derecho a un nivel de vida adecuado que le asegure, así como a su familia, la salud y el bienestar, y, en especial, la alimentación, el vestido, la vivienda... La maternidad y la infancia tienen derecho a cuidados y asistencia especiales.»Es obvio que esto implica el derecho a los medios para poder disfrutar de este derecho y sin un volumen mínimo de agua la salud es imposible como es imposible conseguir del campo los suficientes alimentos.

El Pacto Internacional de Derechos Económicos, Sociales y Culturales, así como el Pacto Internacional de Derechos Civiles y Políticos obliga a los estados a tomar las medidas legislativas y de otra índole para asegurar a sus súbditos el posible disfrute de estos derechos humanos. El artículo $11 \mathrm{del}$ primer convenio arriba mencionado declara que: «Los Estados presentes en este Pacto reconocen el derecho de toda persona a un adecuado nivel de vida para él y su familia, incluyendo comida adecuada, vestido y vivienda, y a la mejora continua de sus condiciones de vida»y el artículo 12 dice «Los Estado presentes en este Pacto reconocen el derecho de toda persona a disfrutar del más alto nivel posible de salud física y mental... Los pasos a dar ... para la realización de estos derechos incluye aquellos necesarios ... para evitar y controlar las epidemias y las enfermedades endémicas y ocupacionales». Y el segundo convenio arriba también mencionado declara, en su artículo 6, que «Todo ser humano tiene un derecho fundamental a la vida. Este derecho será protegido por ley... ». La importancia de estos dos convenios está en que ponen una obligación legal a los estados no sólo a proteger la vida, sino a asegurar las condiciones necesarias para que cada individuo alcance un adecuado nivel de vida que pueda ir mejorando continuamente, y esto es 
totalmente imposible si el individuo y su familia no cuentan con un adecuado suministro de agua para beber, para su higiene personal y para cocinar. La falta de agua dulce en buenas condiciones es, como hemos visto, causa de innumerables enfermedades que, si no matan, al menos reducen la calidad de vida a niveles infrahumanos.

En 1986 La Asamblea General de las Naciones Unidas adoptó la Declaración sobre el Derecho al Desarrollo cuyo artículo 1 dice: «El derecho al desarrollo es un derecho humano inalienable en virtud del cual todo ser humano y todos los pueblos están facultados para participar en un desarrollo económico, social, cultural y político en el que puedan realizarse plenamente todos los derechos humanos y libertades fundamentales, a contribuir a ese desarrollo y a disfrutar de él»y el párrafo 1 del artículo 3 responsabiliza a los estados para «crear las condiciones nacionales e internacionales favorables para la realización del derecho al desarrollo», y el artículo 8 dice: «Los Estados deben adoptar, en el plano nacional, todas las medidas necesarias para la realización del derecho al desarrollo y garantizarán, entre otras cosas, la igualdad de oportunidades para to dos en cuanto al acceso a los recursos básicos, la educación, la salud, los alimentos... ». Interpretando este artículo 8, las Naciones Unidas en 1995 declararon que «a situación de subdesarrollo en la que millones de seres humanos no tienen acceso a cosas tan esenciales como la alimentación, el agua... representa una clara y flagrante violación de sus derechos humanos». Interpretando el concepto de «recursos básicos»y el de «necesidades humanas vitales» han hecho referencia explícita al agua «Al determinar las necesidades vitales del hombre, hay que poner especial atención a la necesidad de suficiente agua para mantener la vida, incluyendo tanto agua para beber como agua necesaria para la producción de alimentos».

En la Declaración Universal de los Derechos del Niño aprobada en 1959 ya se declaraba en el artículo 20: «El niño gozará de una protección especial y dispondrá de oportunidades y servicios dispensado de todo ello por la ley y por otros medios, para que pueda desarrollarse física, mental, moral, espiritual y socialmente, en forma saludable y normal» y en el artículo 3ㅇel niño tiene derecho a crecer y a desarrollarse en buena salud», pero sabemos que el primer obstáculo para el desarrollo físico y la primera causa de muerte de los niños de los países pobres son las enfermedades derivadas, bien de la falta de agua, bien del consumo de agua en malas condiciones

Es obvio que, aunque no se diga explícitamente, en todos estos documentos oficiales internacionales se asume que el agua es el factor primordial del desarrollo tanto de la persona humana como de los pueblos. Sin agua no 
puede haber desarrollo porque no puede haber vida. Fue finalmente el 11 de noviembre del 2002 cuando por primera vez las Naciones Unidas reconocieron explícitamente el agua como un derecho fundamental de la persona humana. Esto se hizo al aprobar una «observación general»o interpretación hecha por el Comité de Derechos Económicos, Culturales y Sociales de los artículos 11 y 12, arriba mencionados, del Pacto Internacional de Derechos Económicos, Sociales y Culturales. El documento aprobado declara explícitamente que «el derecho humano al agua potable es fundamental para la vida y la salud. Agua potable suficiente y segura es una precondición para la realización de todos los derechos humanos»y, al explicar el contenido normativo de este derecho, el Comité afirma que «el derecho al agua potable supone para cada ser humano el derecho a agua potable suficiente, segura, a un precio a decuado y de fácil acceso para cubrir las necesi dades diarias del individuo para beber, cocinar e higiene personal de acuerdo con la dignidad humana».

Al explicar las características del agua que debe estar disponible, el Comité especifica:

Suficiente: normalmente, 50 litros por persona y día, pero nunca menos de 20 litros.

Segura: libre de microbios y otras sustancias que supongan un peligro para la salud.

A un precio adecuado: el gasto en agua no debe poner en peligro el disfrute de otros derechos fundamentales del individuo.

Accesible: to dos deben tener acceso al agua dentro de unos límites físicos adecuados, si es posibleen la misma casa o a distancias cercanas y en número suficiente.

El Comité termina afirmando que los Estados signatarios del Pacto tienen la obligación de dar los pasos necesarios, utilizando todos los recursos disponibles, para asegurar progresivamente el derecho fundamental al agua.

El Consejo Europeo sobre Derecho del Medioambiente también aprobó una resolución en agosto del 2000 reconociendo el derecho al agua con estas palabras:

"1. Toda persona tiene derecho en cantidad y calidad suficientes para su vida y salud.

2. Los poderes públicos deben adoptar las medidas necesarias para favorecer el acceso al agua para todos y ejercer un control sobre las actividades de los diversos organismos, públicos y privados, que intervengan en la gestión del servicio de abastecimiento de agua". 
Y recomienda: a) que los poderes públicos velen por una tarificación apropiada del agua potable por los organismos encargados del abastecimiento del agua, de forma que esta siga siendo asequible a todos; b) que una parte importante de la ayuda al desarrollo en los países insuficientemente equipados se dedique al abastecimiento de agua potable y al saneamiento de las aguas residuales.

\section{Conclusiones}

Para la solución del problema del agua deberían tenerse en cuenta los siguientes doce principios:

1. El acceso a una cantidad adecuada de agua es un derecho fundamental de la persona humana y, como tal, ha de ser protegido por los poderes públicos.

2. Será obligación de los poderes públicos proveer a sus ciudadanos de agua a precios accesibles para todos.

3. El agua será considerada siempre un bien público y los sistemas de agua serán propiedad de las autoridades nacionales y locales.

4. En el análisis de coste-beneficio en los servicios de agua y saneamiento se tomará en cuenta el beneficio social más que el beneficio económico.

5. Para el aprovisionamiento del agua y la construcción y mantenimiento de los servicios de saneamiento los gobiernos podrán pedir la ayuda a aquellas empresas privadas que estén dispuestas a trabajar bajo el control de los poderes públicos.

6. En la solución de los problemas del agua en general se contará siempre con la participación de las comunidades locales y, al tratarse del agua para el hogar, con la participación especial de las mujeres.

7. Los países ricos ayudarán a los países pobres a obtener los medios necesarios para proveer de agua a todos sus ciudadanos.

8. El agua será protegida para que no se «cosifique» y no esté sometida a acuerdos comerciales, ni se permita la creación de monopolios en el sector de provisión y saneamiento.

9. La privatización del agua no será nunca una condición para la remisión de la deuda externa de un país, ni para la obtención de créditos. 
10. Es responsabilidad de todos, individuos, gobiernos e instituciones el evitar el despilfarro en el uso del agua, con un uso más racional y responsable.

11. Todos contribuirán a evitar fugas de agua en las conducciones tanto urbanas como agrícolas.

12. Todos serán responsables de mantener el agua y sus fuentes limpias y libres de cualquier tipo de contaminación.

Pero, dicho esto, no hay que olvidar que el problema del agua es sólo una parte del problema global de la pobreza. Lo primero que hay que tener en cuenta es que el problema del agua para millones de personas no es más que un aspecto más del problema de la pobreza de estas gentes. La escasez de agua es sólo un eslabón en este mortal círculo vicioso de la pobreza. La gente no tiene dinero para pagar ni siquiera unos servicios mínimos como el agua, y las autoridades, debido a la pobreza de la gente, son incapaces de obtener los fondos necesarios para ofrecer estos servicios básicos, y así la escasez de agua es al mismo tiempo la causa y el efecto de la pobreza del país y de los individuos de este país. La falta de agua es más un indicador de pobreza que la causa de esta pobreza, no hay ricossin agua ni pobres con agua. Por tanto, la solución del problema del agua y de los servicios de saneamiento está más allá del sector del agua; está en la erradicación de la pobreza, en el desarrollo socioeconómico y político del país. Cualquier esfuerzo que se haga para erradicar la pobreza de una comunidad será un esfuerzo para proveerlos del agua que necesiten. La pobreza es un fenómeno global que hay que atacar

globalmente, y el problema del agua ha de resolverse como parte de la lucha general contra la pobreza.

\section{Bibliografía}

Abrahams, L., (2003), "Poverty and Water Supply and Sanitation Services" en Features, may/june.

Abu-ZAid, (2003), Closing Remarks in the 3erd World Water Forum, Kyoto.

Agence France Press, (2003), "Water, the Looming Source of Water Conflict". Press Release marzo.

Albanese, M., (2001), India antigua: desde sus orígenes al siglo XIII d.C., Barcelona, Folio. 
Amnesty Internacional, (2003), "Water as a Right". Press Release, junio.

Anon, (2003), "El Eufrates.10.000 años de lucha por el agua” en Geo, № 192. Enero, pp. 44 y ss.

Anon, (2003), "Principales compañías transnacionales en el sector del agua y saneamiento" en Mundo Negro № 472, mayo, pp. 40 y ss.

Australian Brodcasting Corporation, (2002), "Water War's Risk Rises Up International Agenda" en Great Lakes Directory, Sept.

BARANDAT, JöRg, (2001), “La lucha por el agua. Cuencas compartidas y derecho internacional" en D+C Desarrollo y Cooperación, no 6 Nov/Dic, pp 8 y ss.

Barlow, M., (2002), "The Road to Kyoto World Water Forum" en The Guardian, febr 26.

Brewster, HARRY, (1997), River Gods in Greece. Myths and Mountain Waters in the Hellenic World. I.B., NewYork, Tauris.

Caplan, R., (2003), "World Water Warriors. Report from Kyoto World Water Forum" en The Alliance for Democracy, march.

Carrera, Fco., (2003), “La Comercialización de un Derecho básico” en Mundo Negro, no 272, marzo, pp. 34 y ss.

CHIRAC, J., (2003), "Discurso Inaugural del $3^{\text {er }}$ Foro Mundial sobre el Agua” en France Diplomatique, june.

EditoRial, (2003), “Kyoto: Privatización del agua: Banco Mundial vs. ONG`s” en Latierrasinmal, 22 marzo.

Editorial, (2003), “No al comercio del agua” en Mundo Negro, no 472 marzo.

Editorial, (2002), "Water War Likely in Next Decade" en The Guardian, agosto.

Eliade, MirCEA, (1980), Historia de las Creencias y de las ideas religiosas. Cinco volúmenes, Madrid, Ediciones Cristiandad.

FERNÁNDEZ-J ÁUREGUI, C.A., (2002), “El agua como fuente de conflictos: repaso de los focos de conflicto en el mundo" en Revista CIDOB d'Affers Internacionals. Número monográfico sobre "Agua y Desarrollo", no 45 y 46.

Gleick, P., (2003), "The Human Right to Water" en Water Policy, june, p. 487y ss.

GLEICK, P.H., (2000), "Water Conflict Chronology" en Pacific Institute for Studies in Development Environment and Security. 
GleICK, Ph., (1994), "Water, War and Peace in the Midle East" en Environment, vol 36, no 3, pp.6 y ss.

Griaule, Marcel, (1987), Dios de Agua: la cosmogonía del pueblo dogón, Barcelona, Alta Fulla.

Guerquin, F., Ahmed, T., Hua, T., Ikedat, T., Ozbilen, V., Schttelaar, M., (2003), World Water Actions: Malking Water Flow for All, World Water Council.

Humbert, J., (1988), Mitología Griega y Romana. 24ạ edicion, Barcelona, Gustavo Gili.

IPPR, (2003), "Development Targets cannot be met without clean water and safe sanitation", Press Release. March.

KlaRe, M.T., (2003), Guerras por los recursos. El futuro escenario del conflicto global, Barcelona, Tendencia.

KucINICH, D., (2003), "Water as a Human Right" en Dennis Kucinich Speaks, june.

Petrella, R., (2002), El Manifiesto del Agua, Barcelona, Intermon Oxfam.

Postel, S., (1992), The Last Oasis: Facing Water Scarcity, Books News, Inc. Portland

RoAf, M., (2000), Mesopotamia y el Antiguo Oriente Medio, Atlas Culturales del Mundo Barcelona, Folio.

San Miguel, S., (2003), "Water Could Be Source of Future Conflicts" en Canoe, march 2003.

U.N. International Law Commission, (1977), Convention on the Law of the Nonnavigational Uses of International Watercourses. Texto completo.

UNESCO, (2002), Programa Mundial de Evaluación de los Recursos Hídricos. (WWAP), La Haya.

VArios, (2002), Himnos Mágicos de la Antigua India. El Atharva Veda, Biblioteca de la Barcelona, Sabiduría Oriental. RBA.

Varios, (1971), The Thirteen Principal Upanishads. Translated from the Sankrit by Robert Ernest Hume, London, Oxford University Press. Second Edition Revised.

WhiteHouse, R., y Wilkins, J., (2000), Los Orígenes de las Civilizaciones, Atlas Culturales del Mundo, Barcelona, Folio. 
WHO, (2002), “Agua para la Salud: un Derecho Humano", Press Release, 27 nov.

WiLkins, W.J ., (1998), Mitología Hindú, Barcelona, Comunicaciones S.A.

World Water Forum, (2003), "3erd World Water Forum Concludes. 100 New Commitments Made", Press Release, Kyoto, march.

WORLDWATCH, (1997), "Governments failing to protect from spreading water scarcity", Press Release, june.

Wouters, P., (2003), "Water for Peace" en University of Dundee Magazine, may.

WOUTERS, P., (2003), "The Legal Response to International Water Scarcity and Water Conflicts: The UN Watercourses Conventions and Beyond" en Features, may/june 2003.

Wouters, P., Salman, S.M., J ones P., (2003), “The Legal Response to the World's Water Crisis: What Legacy from the Hague? What Future for Kyoto?", Paper presented at the Kyoto World Water Forum. 